\title{
Impact of gene patents and licensing practices on access to genetic testing for inherited susceptibility to cancer: Comparing breast and ovarian cancers with colon cancers
}

\author{
Robert Cook-Deegan, $M D^{I}$, Christopher DeRienzo, $M D, M P P^{2}$, Julia Carbone, LLB, LLM ${ }^{3}$, \\ Subhashini Chandrasekharan, $P h D^{I}$, Christopher Heaney, $B A^{1}$, and Christopher Conover, PhD
}

\begin{abstract}
Genetic testing for inherited susceptibility to breast and ovarian cancer can be compared with similar testing for colorectal cancer as a "natural experiment." Inherited susceptibility accounts for a similar fraction of both cancers and genetic testing results guide decisions about options for prophylactic surgery in both sets of conditions. One major difference is that in the United States, Myriad Genetics is the sole provider of genetic testing, because it has sole control of relevant patents for BRCA1 and BRCA2 genes, whereas genetic testing for familial colorectal cancer is available from multiple laboratories. Colorectal cancer-associated genes are also patented, but they have been nonexclusively licensed. Prices for BRCAI and 2 testing do not reflect an obvious price premium attributable to exclusive patent rights compared with colorectal cancer testing, and indeed, Myriad's per unit costs are somewhat lower for BRCA1/2 testing than testing for colorectal cancer susceptibility. Myriad has not enforced patents against basic research and negotiated a Memorandum of Understanding with the National Cancer Institute in 1999 for institutional BRCA testing in clinical research. The main impact of patenting and licensing in $B R C A$ compared with colorectal cancer is the business model of genetic testing, with a sole provider for $B R C A$ and multiple laboratories for colorectal cancer genetic testing. Myriad's sole-provider model has not worked in jurisdictions outside the United States, largely because of differences in breadth of patent protection, responses of government health services, and difficulty in patent enforcement. Genet Med 2010: 12(4):S15-S38.
\end{abstract}

Key Words: patents, intellectual property, breast cancer, colorectal cancer, colon cancer, Lynch syndrome, FAP, familial adenomatous polyposis, BRCA, APC, MSH, Myriad Genetics, genetic testing

\section{EXECUTIVE SUMMARY}

A natural case study in the field of cancer genetics enables us to compare the development of testing for inherited susceptibility to colorectal cancers with inherited breast and ovarian cancers. Specific mutations in the BRCA1 and BRCA2 genes can dramatically increase patients' risks for breast and ovarian can-

From the ${ }^{1}$ Center for Public Genomics, Center for Genome Ethics, Law \& Policy, Institute for Genome Sciences \& Policy, Duke University; ${ }^{2}$ Duke Medical School and Sanford Institute of Public Policy, Duke University; ${ }^{3}$ Duke Law School; and ${ }^{4}$ Center for Health Policy and Sanford Institute of Public Policy, Duke University.

Robert Cook-Deegan, Center for Genome Ethics, Law \& Policy, Institute for Genome Sciences \& Policy, Duke University, Box 90141, Durham, NC 27708. E-mail: gelp@duke.edu.

Disclosure: Christopher DeRienzo, MD, MPP, was paid directly as a consultant to the Secretary's Advisory Committee for Genetics, Health and Society, summer 2007. The other authors declare no conflict of interest. See Acknowledgments for details.

DOI: $10.1097 /$ GIM.0b013e3181d5a67b cers; Myriad Genetics, Inc., holds broad patents on both of these genes and their mutations in the United States. Similarly, specific mutations in several other genes can give rise to two inherited conditions highly associated with developing colorectal cancer, known as Lynch syndrome (or hereditary nonpolyposis colorectal cancer [HNPCC]) and familial adenomatous polyposis (FAP), but the involved gene patents are predominantly held by nonprofit institutions and licensed nonexclusively. Myriad is the sole provider of full-sequence $B R C A$ testing in the United States. For FAP, Myriad and four nonprofits offer full-sequence analysis of the FAP-associated adenomatous polyposis coli $(A P C)$ gene (and from some testing services, another gene, $M Y H$ ). For Lynch syndrome, Myriad, Quest Diagnostics, Huntington Diagnostic Laboratories, and four nonprofits offer full-sequence analysis for three HNPCCcausing genes ( $M L H 1, M S H 2$, and MSHO).

The clinical decision tree and the role of full-sequence genetic testing differs between $B R C A$ and colon cancer predisposition (and details about exactly how best to do genetic testing for colorectal cancer are particularly unsettled). However, for purposes of comparing the impact of patents and licensing practices, those uncertainties about clinical practice do not directly interfere with expected effects attributable to patents and licensing.

\section{Basic and clinical research}

- As of September 2008, Myriad has submitted $>18,000$ entries ( $>80 \%$ of total entries) for $>2,600$ unique mutations to the Breast Cancer Information Core database and cites $>4,300$ follow-up publications on BRCA1 and $B R C A 2$ (as of February 2005) and $>100$ individual research projects (including a 1999 Memorandum of Understanding [MOU] with the National Cancer Institute [NCI]) as evidence that it supports research. ${ }^{1,2}$

- Some argue that Myriad's definition of infringing research is too broad. Specifically, Myriad asserted that even though Genetic Diagnostics Laboratory (GDL) limited testing to patients in NCI research protocols, because GDL was performing a third-party service for which it charged other laboratories, it infringed the patent. As Parthasarathy says, "So long as GDL disclosed results to the patient, [it provided] a commercial service and violat[ed] the patent."3

- NCI Director Richard Klausner signed a December 1999 MOU that included an explicit definition of genetic testing for research. The crucial definition was of "Research Testing Services:" "[P] $]$ art of the grant supported research of an Investigator, and not in performance of a technical service for the grant supported research of another (as a core 
facility, for example). Research Testing Services are further defined as paid for solely by grant funds, and not by the patient or by insurance." That MOU provided deeply discounted testing for any NCI-funded project with no reach-through rights to new discoveries. Under this definition, researchers could perform research testing within their institutions without a license from Myriad. ${ }^{4}$

- A 2005 Lewin Group 5 report concluded that, based on incentive effect theory, Myriad's exclusive patents on the $B R C A$ genes stifled further basic research; however, few empirical data support or refute the Lewin Group's conclusion.

- Although Myriad maintains it has not enforced its patents against researchers, it has not publicly stated that it would not do so in a written, actionable form except in the NCI MOU. This ambiguity may itself be a factor in stifling further research to the extent that this has occurred.

- Myriad responds that it collaborates with many academic groups, and they simply have to contact Myriad. This is only a partial remedy, however, as contacting Myriad would alert the patent holder about actions it could regard as infringement.

- A recent controversy in Australia, precipitated when Myriad's licensee Genetic Technologies Ltd. (GTG) announced it would reverse its 2003 announcement allowing testing laboratories to do $B R C A$ testing without a license, led it to clarify that its license does not cover research testing, and so any enforcement for research use would be from Myriad or the University of Utah (neither of which has indicated any intention to enforce against research use in Australia). (See Text box for more details.)

\section{Development}

- A 2003 French study on the cost-effectiveness of fullsequence $B R C A$ testing versus other methods stated:

The results of our cost-effectiveness analysis strongly suggest that negative [monopolistic] effects of this kind are occurring in the case of BRCA1 ... [Such monopoly control] may prevent health care systems from identifying and adopting the most efficient genetic testing strategies. $^{6}$

- The same study found that:

...there exist alternative strategies for performing BRCA1 diagnosis: prescreening techniques such as FAMA [fluorescent assisted mismatch analysis] and, potentially, DHPLC [denaturing high performance liquid chromatography] or DGGE [denaturing gradient gel electrophoresis], based on the current estimates of their sensitivity, would minimize the cost of diagnosis while also ensuring a comparable level of effectiveness to that of applying DS [direct sequencing] to the entire gene. ${ }^{6}$

These uncertainties for $B R C A$ testing parallel the uncertainty about which genetic testing protocols are optimal for colorectal cancer susceptibility, except that in the case of $B R C A$ testing, Myriad is the only testing service in the US market, and so its practices are a de facto standard, whereas practices for colon cancer vary among health care providers.
- Myriad notes that its sequencing technologies are a gold standard method, as alternatives are confirmed by sequence analysis. ${ }^{1}$ Some health systems outside the United States have chosen to use a diagnostic decision tree that uses full-sequence analysis later in the process and, more selectively, to reduce expenses. We know of no head-tohead comparison studies on health outcomes. The comparable comparative studies for colon cancer testing found no clear "winner" strategy among four examined, one of which was initial full-sequence testing of multiple genes. ${ }^{7,8}$

- By using multiplex ligation-dependent probe amplification (MLPA), a 2006 study published in the Journal of the American Medical Association (JAMA) noted that Myriad's testing strategy (short-range polymerase chain reaction [PCR] followed by genomic sequencing) missed up to $12 \%$ of large genomic deletions or duplications. ${ }^{9}$ This led to criticism of the Myriad test algorithm. In congressional testimony on October 30, 2007, Drs. Marc Grodman and Wendy Chung attributed this problem to Myriad's soleprovider status and patent monopoly. ${ }^{10}$ Dr. Chung stated, "It was only after considerable pressure from the scientific community that the company added methods to detect these deletions, insertions, and rearrangements in 2006, over 10 years after they first introduced clinical genetic testing, and barred anyone else from performing the tests. In a competitive marketplace, this delay never would have occurred." 11

- Myriad disagrees with this characterization. Myriad notes it launched testing for the five most common rearrangements (accounting for about a third of all rearrangements) in 2002 and, simultaneously, began developing testing for all large rearrangements $\left(\right.$ BART $\left.^{\circledR}\right)$ that it launched in 2006 for the higher risk patients (similar to the JAMA article's criteria) as part of its BRACAnalysis ${ }^{\mathrm{TM}}$. This technology was the subject of poster presentations in 2004. After the Walsh et al. ${ }^{9}$ article was published, Myriad issued Clinical Update, Vol. 4, No. 5, "Testing for Hereditary Breast and Ovarian Cancer Syndrome," in September 2006. It cited ongoing work and intention to have a test for large-scale rearrangements by later that year. An abstract submitted February 2004 and a poster presented fall 2004, which report on Myriad efforts to detect large-scale rearrangements, were cited in that update. ${ }^{12-14}$ Myriad notes that rearrangement testing it was already conducting would have detected roughly one third of the "missing" cases reported in the JAMA article, so the problem was overstated, and Myriad incorporated more extensive testing for rearrangements in 2006, the year the JAMA article appeared. Myriad's first year of conducting large-scale rearrangement testing is described in Spence et al. ${ }^{15}$

- The congressional testimony also alluded to limits on availability of $B R C A$ tests in forms that Myriad itself does not perform. This includes testing of paraffin-embedded samples or preimplantation genetic diagnosis (PGD). Some patients and families lack access to a relative's blood (but potentially with access to a deceased relative's preserved paraffin-embedded tumor sample). Myriad states it has not enforced patents for services it does not provide (such as paraffin-embedded tissues) and has sublicensed $B R C A$ testing to three laboratories offering PGD. An article in the New York Times quotes William Hockett, MD, of Myriad Genetics and states that preimplantation $B R C A$ testing had been licensed to three fertility clinics. ${ }^{16} \mathrm{~A}$ search of www.genetests.org shows several foreign $B R C A$ prenatal testing services (not necessarily PGD, but Myriad 
does not offer any form of prenatal testing) and two US services, at the University of California at San Francisco, and Boston University. Online research also found two services offering preimplantation $B R C A$ mutation detection: at Reproductive Genetics Institute in Chicago and Genesis Genetics Institute in Detroit.

\section{Commercialization}

- A centralized testing service offers some benefits, including Myriad's ability to provide free testing to first-degree relatives once a mutation has been identified to further characterize uncertain variants. Testing is Clinical Laboratory Improvement Amendments (CLIA)-certified and reportedly has faster turnaround time than most other laboratories, and Myriad's reports are characterized as clear and detailed.

- Based on available data as described in the text (derived primarily from phone calls to testing laboratories and online pricing guidelines), calculating the price for each genetic test per DNA segment amplified by PCR (an "amplicon") yields a rough estimate of Myriad's patent premium:

- For BRCA, Myriad charges $\$ 3120$ total or $\$ 38.05$ per amplicon (including separate testing for common rearrangements).

- For FAP-where Myriad has four competitors-Myriad charges $\$ 1795$ or $\$ 40.80$ per amplicon (including Southern Blot rearrangement and insertion-deletion testing plus two common mutations of the MYH gene).

- Nonprofit competitors' prices range from \$1200-1675 (\$28.57-39.88 per amplicon) although rearrangement testing is generally not included in this price.

- For HNPCC - where Myriad has six competitors-Myriad charges $\$ 2950$ or $\$ 49.17$ per amplicon (for three genes, which includes Southern Blot testing for insertions, deletion, and rearrangements).

- Nonprofit competitors' prices range from \$1800-4646.16 (\$30.00-77.44 per amplicon) and, generally, do not include rearrangement testing.

- These data show little consistent price effect of the $B R C A$ patents, based on two-step logic: first, comparing intralaboratory cost per amplicon for Myriad's testing of BRCA versus colon cancer genes and second, comparing Myriad's price for full-sequence testing of colon cancer genes compared with other (competitor) services. (For discussion of variables that cannot be controlled and may confound the comparison, see Limitations on price comparison below).

- An analysis done in three French public hospitals showed the incremental costs of testing an additional family member with a previously identified $B R C A$ mutation is only $17 \%$ of the price charged by Myriad. ${ }^{6}$ An alternative technology of two-dimensional electrophoretic mutation scanning was claimed to be highly sensitive but possible as a screening test, estimated at $\$ 70 /$ test and perhaps possible to reduce to $\$ 10$ / test direct costs. ${ }^{17}$

- Alternative low-cost testing methods may be used in some health systems, but not in the United States; these low-cost alternative methods have not been adopted widely for colon cancer testing either, and effects are, therefore, not specific to $B R C A$ testing or patent status. Any failure to adopt alternative technologies cannot be directly attributed to the $B R C A$ patents or sole-provider status. However, patent impediments to adoption of inexpensive technologies cannot be excluded entirely because colon cancer sequences and testing methods are also patented.

- A controversy about $B R C A$ testing in Australia erupted in July 2008, when GTG, the BRCA licensee in Australia and New Zealand, announced it would enforce its patents against unlicensed laboratories in Australia. GTG sent "cease-anddesist" letters with an initial deadline of October 2008, and then extended to November 2008. On 31 October, GTG announced it "suspended any enforcement activity pending the outcome of further dialogue with all relevant stakeholders."18 (See Text box for an update.)

- Myriad mainly benefits from the volume it receives as a monopoly provider of $B R C A$ testing. Myriad can direct all US full-sequence $B R C A$ tests to its laboratories, and we have learned of European reference laboratories that also use Myriad, either directly or through its licensed foreign laboratories, because of turnaround time and reliability. Any price effect attributable to patent status is equivocal; the volume effect is unequivocal.

\section{Communication/marketing}

- Marketing can increase awareness of BRCA mutations in the general and at-risk patient populations.

- A survey of 300 women following Myriad's 2002 public advertising campaign noted $85 \%$ "would contact their physician regarding $B R C A$ testing" and $62 \%$ would switch providers to find one who offered the test. ${ }^{19}$

\section{Adoption by clinical providers and testing laboratories}

- Provider, laboratories, and third-party payer metrics of testing services are only rough proxies for patient access.

- A 2003 survey of laboratory directors demonstrates nine instances of patent enforcement by Myriad on its $B R C A$ patents. The same directors noted two FAP patent enforcements and zero Lynch syndrome (HNPCC) patent enforcements. ${ }^{20}$ FAP and HNPCC "patent enforcements" are more unlikely given nonexclusive licensing and multiple rights holders.

- BRCA accounted for two cases of gene patent litigation and colon cancer genes for none (of 31 collected gene patent litigation cases, 5 were related to diagnostics). ${ }^{21}$ Two gene patent lawsuits between OncorMed and Myriad (accounting for two cases in Holman's count, a suit and countersuit) were consolidated into a single case, and then settled out-of-court, with Myriad gaining control of OncorMed's $B R C A$ patent rights. The other Myriad-University of Pennsylvania lawsuit over $B R C A$ testing was settled even earlier in the process. 


\section{Adoption by third-party payers}

- Based on available data and authors' calculations, if gene patents conferred a premium of $\$ 750$, this would reduce the likelihood of third party coverage by $11 \% .^{22}$

- In one study, only $59 \%$ of women undergoing full-sequence $B R C A$ analysis filed a health insurance claim $(99 \%$ of whom had insurance). ${ }^{23} \mathrm{~A}$ second study found that $15 \%$ of women seeking $B R C A$ analysis chose to self-pay for their services and that every woman did so in fear of insurance or employment discrimination. ${ }^{24}$

- The published data do not reflect two major trends. One is the May 2008 enactment of the Genetic Information Nondiscrimination Act, which may reduce fear of $B R C A$ testing having consequences for health insurance and employment. The other is Myriad's current experience with third-party payers, with self-pay reported as having dropped to $\sim 5 \%$ as more insurers and health plans cover testing in high-risk patients. Average reimbursement pays for $>90 \%$ of charges (so, average co-pay is $<10 \%$; W. Rusconi, Vice President of Marketing, Myriad Genetic Laboratories, personal communication, 2008).

- Adoption by third-party payers is becoming more common. Individuals who are not covered are either uninsured (some of whom qualify for Myriad's financial assistance program) or covered by state Medicaid plans for which reimbursement is evolving (and some Medicaid programs have been slow to adopt $B R C A$ testing). A small percentage (5-10\%) of private insurance plans fails to cover any kind of genetic testing (whether it is BRCA, HNPCC, or even cystic fibrosis). This is often because of policy or blanket exclusions on the molecular diagnostic CPT codes through which genetic tests are reimbursed. (CPT codes are billing codes for reimbursement of health services. CPT ${ }^{\circledR}$ is formally a trademarked term that refers to a system of Current Procedural Terminology maintained by the American Medical Association.)

\section{Consumer utilization}

- Consumers may pay a different price for a given genetic test depending on whether or not insurance covers it, which holds true for both Myriad Genetics and nonprofit providers.

- Although early publications estimated that as many as $19-74 \%$ of at-risk individuals who could benefit from $B R C A$ testing were not being tested (W. Rusconi, personal communication, 2008), no systematic evaluation of this question has been conducted as coverage and reimbursement have become more common. The Genetic Information Nondiscrimination Act of 2008 will take effect in 2009 (health insurance provisions) and 2010 (employer provisions), and this may also affect use of genetic testing, including breast and ovarian cancer and family risk of colon cancer.

- Companies offering genetic testing have incentives to negotiate the complex coverage and reimbursement landscape on behalf of patients using their services. In one study, nearly $70 \%$ of patients eligible for free $B R C A$ testing elected to get tested; however, cost certainly matters because only $22 \%$ of self-pay patients in the same sample chose to be tested (W. Rusconi, personal communication, 2008). These data are out-of-date as Myriad reports only $\sim 5 \%$ self-pay in recent experience.

- Any price effect of the BRCA patents is buried in the noise once prices are normalized, first by comparing Myriad's prices for $B R C A$ to its price for colon cancer gene testing and then by comparing Myriad's prices for colon cancer gene testing to other providers. Myriad's costs per unit are lower for $B R C A$ full-sequence testing than for colon cancer gene tests. Its prices are higher than some nonprofit colon cancer testing services for FAP, although Myriad includes rearrangement testing and comparison services that are priced differently by other providers. Myriad is midrange among providers of Lynch syndrome (HNPCC) testing (and low relative to the one for-profit HNPCC testing service). This makes it impossible to calculate a meaningful price premium for $B R C A$ testing or to conclude that $B R C A$ patents have led to prices far above comparable tests for other conditions provided by other laboratories.

- It is, therefore, difficult to attribute reduced access to $B R C A$ testing to patents. We cannot exclude the possibility that patent holder's investments in education about hereditary breast and ovarian cancer and testing have actually had the opposite effect of increasing access to testing.

\section{INTRODUCTION}

One natural case study in the field of cancer genetics can address whether and to what degree intellectual property law affects patients' access to genetic testing. The parallel discovery of inherited mutations for two classes of cancer: breast, ovarian, and some other cancers associated with $B R C A 1 / 2$ genes, compared with a cluster of genes in which mutations predispose to cancer of the colon and rectum. Specific mutations in genes known as BRCA1 and BRCA2 can dramatically increase patients' risks for breast cancer and ovarian cancer (and more rarely, some other cancers). Similarly, specific mutations in other genes can give rise to two inherited conditions highly associated with developing colon cancer, known as FAP and Lynch syndrome (sometimes called hereditary nonpolyposis colorectal cancer [HNPCC]).

Mutations in all six cancer susceptibility genes were discovered in the 1990s, and genetic tests to detect them were patented over a 4-year period. Myriad Genetics, Inc., a for-profit company, gained control over the US patents on genetic tests for $B R C A 1$ and BRCA2. The patents for inherited colon cancer family syndromes remain more broadly distributed, with some key patents held by Johns Hopkins University, Oregon Health Sciences University, Dana Farber, and other nonprofit entities. The licensing patterns for these tests vary, again providing a natural case study to compare for-profit patenting and licensing practices versus nonprofit patenting and licensing practices. Finally, as of early 2006, there were 62 genetic tests for cancer available for clinical use but only 5 used for primary prevention, including the tests for $B R C A$, FAP, and Lynch syndrome (HNPCC) discussed in this case study. ${ }^{25}$ 


\section{BACKGROUND: BREAST CANCER, OVARIAN CANCER AND BRCA1/BRCA2}

According to the American Cancer Society (ACS), $>178,000$ American women were diagnosed with invasive breast cancer in 2007 and another 62,000 with in situ or noninvasive breast cancer. This made breast cancer the most common cancer diagnosis after skin cancer for women. Also, $>40,000$ women were expected to die from breast cancer in 2007 , second only to lung cancer. ${ }^{26}$

In 2007, the ACS also projected that 22,430 women were diagnosed with ovarian cancer, accounting for $3 \%$ of all cancers among women. Furthermore, 15,280 women were projected to die from ovarian cancer in 2007, more than any other cancer of the female reproductive tract. ${ }^{26}$

Both breast and ovarian cancer are associated with ageovarian cancer incidence peaks around the age of 70 years, ${ }^{26}$ whereas $95 \%$ of new breast cancer cases and $97 \%$ of breast cancer deaths occur in women over the age of 40 years. ${ }^{27}$ Obesity is also a risk factor for both breast and ovarian cancers, and both cancers correlate with family history.

Approximately $20 \%$ of women with breast cancer have either a first-degree or a second-degree relative with breast cancer. ${ }^{28}$ Scientists have identified several genes associated with elevated risk of breast cancer. Two of these are powerful cancer susceptibility genes, meaning mutations can be traced through families in a classic Mendelian dominant inheritance pattern: $B R C A 1$ and $B R C A 2$. Breast cancers arising from $B R C A 1$ and $B R C A 2$ mutations account for between $5 \%$ and $10 \%$ of all breast cancers ${ }^{27}$ or between 20,000 and 40,000 cases annually. Overall, the relative lifetime risk of breast cancer is 2.7-6.4 times greater for those with $B R C A$ mutations compared with women of average risk (Table 1).

Table 1 Summary table19,20,28,29,103,104

\begin{tabular}{|c|c|c|c|c|}
\hline \multirow{3}{*}{ 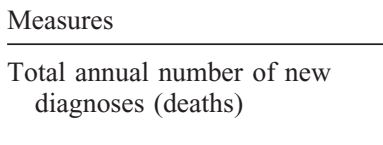 } & \multicolumn{2}{|c|}{ Breast/ovarian cancer $B R C A 1 / B R C A 2$} & \multicolumn{2}{|r|}{ Colorectal cancer HNPCC/FAP } \\
\hline & Breast & $178,480(40,910)$ & Colorectal & $153,760(52,180)$ \\
\hline & Ovarian & $22,430(15,280)$ & & \\
\hline $\begin{array}{l}\text { Percent of cancers caused by } \\
\text { mutation }\end{array}$ & Breast and ovarian & $5-10 \%$ & Colorectal & $\sim 5 \%$ \\
\hline \multirow{2}{*}{$\begin{array}{l}\text { Lifetime percent risk if positive } \\
\text { for mutation }\end{array}$} & Breast & $35-85 \%$ & HNPCC & $80 \%$ \\
\hline & Ovarian & $16-60 \%$ & FAP & $\sim 100 \%$ \\
\hline \multirow{2}{*}{$\begin{array}{l}\text { Lifetime relative risk if positive } \\
\text { for mutation }\end{array}$} & Breast & $2.7-6.4$ & HNPCC & 13.3 \\
\hline & Ovarian & $9.4-35.3$ & FAP & 16.7 \\
\hline \multirow[t]{3}{*}{ Patent holder } & \multirow{3}{*}{\multicolumn{2}{|c|}{$\begin{array}{l}\text { Myriad Genetics, 1998; US 5,753,441 } \\
\qquad(B R C A 1) \text { and US 6,051,379 (BRCA2) }\end{array}$}} & HNPCC & $\begin{array}{l}\text { MLH1 gene: Oregon Health Sciences } \\
\text { University and Dana-Farber, 1999-US } \\
5,922,855\end{array}$ \\
\hline & & & & $\begin{array}{l}\text { MSH2 protein: Johns Hopkins, 1997_US } \\
\text { 5,591,826 }\end{array}$ \\
\hline & & & FAP & $\begin{array}{l}A P C \text { gene: Johns Hopkins, } 1994 \text {-US } \\
5,352,775\end{array}$ \\
\hline \multirow[t]{4}{*}{ US licensees } & \multirow{4}{*}{\multicolumn{2}{|c|}{ Myriad Genetics }} & HNPCC & $\begin{array}{l}\text { Nonprofit: Baylor College of Medicine, Boston } \\
\text { University School of Medicine, City of } \\
\text { Hope National Medical Center, Harvard- } \\
\text { Partner's Center for Genetics and Genomics, } \\
\text { Huntington Medical Research Institutes, } \\
\text { Mayo Clinic, University of PA School of } \\
\text { Medicine }\end{array}$ \\
\hline & & & & For profit: Myriad Genetics, Quest Diagnostics \\
\hline & & & FAP & $\begin{array}{l}\text { Non-profit:Baylor College of Medicine, } \\
\text { Harvard-Partner's Center for Genetics and } \\
\text { Genomics, Huntington Medical Research } \\
\text { Institutes, University of PA School of } \\
\text { Medicine }\end{array}$ \\
\hline & & & & For profit: Myriad Genetics \\
\hline \multirow[t]{4}{*}{ Cost of genetic test } & \multirow{4}{*}{\multicolumn{2}{|c|}{$\$ 3,120$ for two genes }} & HNPCC & $\$ 600-1,800$ for one gene \\
\hline & & & & $\$ 1,200-2,000$ for two genes \\
\hline & & & & $\$ 2,050-2,995$ for three genes \\
\hline & & & FAP & $\$ 1,200-1,800$ for one gene \\
\hline
\end{tabular}

Patent data obtained from Delphion Patent Database. Provider list according to GeneTests.org — limited search to "Analysis of the entire coding region: Sequence analysis." ${ }^{a}$ Purchased from OncorMed in 1998. (See Table 2 for more patent information.) 
For ovarian cancer, the relative risk for $B R C A$-positive women rises 9.3-35.3 times (Table 1).

Although the Agency for Healthcare Research and Quality (AHRQ) notes that BRCA1 and BRCA2 mutations occur at a frequency of $\sim 1$ in $300-500$ in the general population, the risk of inheriting one of these mutations is much higher in some ethnic groups. For example, specific mutations have been identified in the Ashkenazi Jewish population, and certain families in the Netherlands, Iceland, and Sweden have a high frequency of $B R C A 1$ or $B R C A 2$ mutations. ${ }^{27}$ Current clinical practice guidelines are available from the National Comprehensive Cancer Network (NCCN) at http://www.ncen.org.

\section{BACKGROUND: COLORECTAL CANCER AND FAMILIAL ADENOMATOUS POLYPOSIS/LYNCH SYNDROME (HNPCC)}

According to the ACS, colorectal cancer is the third most common cancer among both men and women in the United States. More than 150,000 Americans will be diagnosed with colorectal cancer, and $>52,000$ Americans will die of colon cancer in 2007 , accounting for $10 \%$ of all cancer deaths. ${ }^{26}$ Risk factors for developing colorectal cancer include age, diet, obesity, smoking, physical inactivity, and family history. ${ }^{26}$

Almost one third of colorectal cancer cases are thought to be related to family history, of which two major conditions have been correlated with specific genetic mutations. When combined, these two conditions are thought to account for between $3 \%$ and $5 \%$ of all US colorectal cancers. Current clinical practice guidelines are available from the NCCN at http://www.nccn.org.

\section{Familial adenomatous polyposis}

FAP accounts for $\sim 1 \%$ of all colorectal cancers. The disease is inherited in an autosomal dominant fashion. More than $90 \%$ of FAP cases are associated with mutations in the $A P C$ gene. The $A P C$ gene encodes a tumor-suppressing protein, analogous to the tumor-suppressing gene $p 53$, which is found mutated in many kinds of cancer. The percent of individuals with FAP who develop colorectal cancer approaches $100 \%$ - or 16.7 times the risk of the general population (Table 1) — with most affected individuals developing cancer around the age of 40 years. ${ }^{29} \mathrm{~A}$ milder and less common form of FAP is attributed to mutations in the $M Y H$ gene.

\section{Lynch syndrome (HNPCC)}

Lynch syndrome accounts for $1-3 \%$ of colorectal cancer in the United States, and mutations are inherited in an autosomal dominant pattern. Lynch syndrome is rapidly becoming a disease category defined by DNA characterization, caused by mutations in genes that encode enzymes that repair DNA base pair mismatches during DNA replication. This molecular definition replaces the traditional symptomatic and descriptive label HNPCC.

The most recent review of evidence about genetic testing in this condition defined Lynch syndrome as a "predisposition to colorectal cancer and certain other malignancies as a result of a germline mismatch repair gene mutation-including those with an existing cancer and those who have not yet developed cancer."8 Mutations in specified genes are, thus, becoming the basis for disease classification, replacing and refining previous clinical criteria. Lynch syndrome is becoming the preferred term for those who have these mutations, although we also use HNPCC to refer to the clinical findings in this review.
Individuals must inherit a copy of one mutated gene from either their mother or their father to develop the HNPCC disease. The genes already known to give rise to Lynch syndrome when mutated include MLH1, PMS1, PMS2, MSH6, TFGBR2, and MLH3. ${ }^{30}$ Of these, mutations in MSH2 account for $\sim 60 \%$ of cases and $M L H 1$ another $30 \%$. $^{30}$ "Mismatch repair proteins are responsible for correcting errors that occur during DNA replication, typically the addition or deletion of one or more nucleotides." 29 Patients with Lynch syndrome have $\sim 80 \%$ lifetime risk of developing colorectal cancer-or $>13$ times the risk of the general population (Table 1)-although the specific risk varies by mutation. ${ }^{29}$ There is significantly higher risk of developing endometrial (uterine) cancer and ovarian cancer as well in women with these mutations. In fact, about half of women with Lynch syndrome who develop cancer present with one of these gynecologic cancers as their first malignancy.

\section{PATENTS AND LICENSING}

\section{Breast cancer}

Myriad Genetics owns or has licensed the patents for both $B R C A$ genes and their mutations. Some BRCA1 patents are coassigned to the University of Utah and US Department of Health and Human Services, as the research was supported in part by National Institutes of Health [NIH] grants (governed by the Bayh-Dole Act) and intramural research at the National Institute of Environmental Health Sciences (governed by the Stevenson-Wydler Act). Although NIH investigators were listed a coinventors on some patents, NIH assigned administration of those patents to the University of Utah. The $B R C A$ patents have been administered by the University of Utah, with exclusive licensing to Myriad, and Myriad, in effect, controls the patent rights. We, therefore, refer to them as "Myriad patents."

Myriad's first patent, US 5,753,441, is on BRCA1 testing and includes both method claims and a testing kit. Its second patent, US $6,051,379$, is on BRCA2 and includes parts of the $B R C A 2$ gene in oligonucleotide sequences, method claims, and kits. According to Dr. Shobita Parthasarathy, Myriad purchased this patent along with testing services from OncorMed in 1998 for an "undisclosed sum."19 Patent rights were included in $\$ 525,000$ paid to OncorMed, reported in its Securities and Exchange Commission quarterly report from June 30, 1998. ${ }^{31}$ (For more information on patents, see Table 2.) Having sold off its $B R C A$ assets, OncorMed entered into a reorganization agreement in which the company Gene Logic, Inc., bought OncorMed for a sum "not to exceed approximately \$38 million." 32 OncorMed registered its termination with the Securities and Exchange Commission on September 30, 1998. ${ }^{33}$

Myriad became the sole provider for both $B R C A 1$ and $B R C A 2$ full-sequence tests in the United States, as shown in Table 1. "To perform BRCA1/2 mutation analysis, Myriad Genetics and its licensees only use direct sequencing of the whole genomic DNA (DS [double-stranded]) of both genes (BRACAnalysis $\left.{ }^{\circledR}\right) .{ }^{6}$ In 2003, the Journal of Molecular Diagnostics noted that of the 12 tests that laboratory directors across the United States were called on to stop performing by patent enforcers, Myriad's BRCA testing tied for first with nine laboratories reporting enforcement efforts. ${ }^{20}$

\section{Lynch syndrome (HNPCC)}

Multiple gene patents cover the major genes involved in Lynch syndrome (HNPCC). The first patent, US 5,922,855, 
Table 2 BRCA1 and BRCA2 patents

\begin{tabular}{|c|c|c|c|}
\hline US patent & Nature of claims & Assignee & US licensee \\
\hline $5,654,155$ & $\begin{array}{l}\text { Consensus cDNA sequence for } \\
\text { BRCA1, method for detecting } \\
\text { BRCA1 mutations }\end{array}$ & OncorMed & Rights acquired by Myriad \\
\hline $5,622,829$ & $\begin{array}{l}\text { Mutant allele probes and methods } \\
\text { for } B R C A 1\end{array}$ & University of California & OncorMed (acquired by Myriad) \\
\hline $5,693,473$ & $B R C A 1$ mutations & $\begin{array}{l}\text { Myriad Genetics; Centre du Recherche du Chul; } \\
\text { Tokyo Cancer Institute }\end{array}$ & Myriad Genetics \\
\hline $5,709,999$ & $\begin{array}{l}\text { Method for detecting } B R C A I \\
\text { mutations }\end{array}$ & $\begin{array}{l}\text { Myriad Genetics; Centre du Recherche du Chul; } \\
\text { Tokyo Cancer Institute }\end{array}$ & Myriad Genetics \\
\hline $5,710,001$ & $\begin{array}{l}\text { Method for detecting } B R C A 1 \\
\text { mutations in tumors }\end{array}$ & $\begin{array}{l}\text { Myriad Genetics, University of Utah Research } \\
\text { Foundation, and the United States of America }\end{array}$ & Myriad Genetics \\
\hline $5,747,282$ & $\begin{array}{l}\text { cDNA sequence for } B R C A 1, \\
\text { cloning vectors containing } \\
B R C A 1 \text { cDNA, kit for detecting } \\
\text { mutations in } B R C A 1, \text { and } \\
\text { method for screening for } \\
\text { therapeutics for cells with } \\
B R C A 1 \text { mutations }\end{array}$ & $\begin{array}{l}\text { Myriad Genetics, University of Utah Research } \\
\text { Foundation, and the United States of America }\end{array}$ & Myriad Genetics \\
\hline $5,750,400$ & $\begin{array}{l}\text { cDNA sequence for } B R C A 1 \text { and } \\
\text { methods for detecting } B R C A 1 \\
\text { mutations }\end{array}$ & OncorMed & Rights acquired by Myriad \\
\hline $5,753,441$ & $\begin{array}{l}\text { Method and kit for detecting } \\
B R C A 1 \text { germline mutations }\end{array}$ & $\begin{array}{l}\text { Myriad Genetics, University of Utah Research } \\
\text { Foundation, and the United States of America }\end{array}$ & Myriad Genetics \\
\hline $5,837,492$ & $B R C A 2$ sequence and methods & $\begin{array}{l}\text { Myriad Genetics, Endo Recherche, HSC } \\
\text { (Hospital for Sick Children) Research and } \\
\text { Development Limited Partnership, and } \\
\text { Trustees of the University of PA }\end{array}$ & Myriad Genetics \\
\hline $6,045,997$ & $B R C A 2$ sequences and methods & $\begin{array}{l}\text { Duke University and Cancer Research } \\
\text { Campaign (United Kingdom) }\end{array}$ & Expired \\
\hline $6,051,379$ & $\begin{array}{l}\text { Probes, methods, and kits for } \\
\text { detecting } B R C A 2 \text { mutations and } \\
\text { rearrangements }\end{array}$ & $\begin{array}{l}\text { Myriad Genetics, University of Utah Research } \\
\text { Foundation, and the United States of America }\end{array}$ & Myriad Genetics \\
\hline $6,130,322$ & $\begin{array}{l}\text { cDNA sequence for segments of } \\
\text { BRCAI }\end{array}$ & Gene Logic & NA \\
\hline $6,162,897$ & $\begin{array}{l}\text { Amino acid sequence translated } \\
\text { from } B R C A 1\end{array}$ & $\begin{array}{l}\text { Myriad Genetics, University of Utah Research } \\
\text { Foundation, and the United States of America }\end{array}$ & Myriad Genetics \\
\hline $6,686,163$ & $\begin{array}{l}B R C A 1 \text { mutations and cloning } \\
\text { vectors containing mutations }\end{array}$ & Gene Logic & NA \\
\hline $6,720,158$ & $\begin{array}{l}B R C A 1 \text { sequence for splicing } \\
\text { variations }\end{array}$ & $\begin{array}{l}\text { Philadelphia Health and Education, Corp. (now } \\
\text { assigned to Drexel University, Personal } \\
\text { communication with Drexel University Office } \\
\text { of Technology Commercialization, 2008) }\end{array}$ & Unlicensed \\
\hline $6,838,256$ & $\begin{array}{l}\text { BRCA1 consensus coding } \\
\text { sequences, mutations, vector } \\
\text { comprising sequence, and } \\
\text { methods for detecting mutations }\end{array}$ & Gene Logic & NA \\
\hline $6,951,721$ & $\begin{array}{l}\text { Method for determining functional } \\
\text { sequence variations in } B R C A 1\end{array}$ & Gene Logic & NA \\
\hline
\end{tabular}

Duke University researchers requested licensing information from Gene Logic but, to date, have not received licensing information. Information compiled by authors. NA, not applicable.

covering the $M L H 1$ gene, was filed by Oregon Health Sciences University and Dana Farber in 1999. The second patent application, US 5,591,826, was filed by Johns Hopkins in 1997. It covers the MSH2 protein. Johns Hopkins also later patented a diagnostic method to find mutations in the MSH2 gene (US
$5,693,470)$. There are multiple providers, both nonprofit and for-profit, for full-sequence tests on both genes (see Table 1). Neither patent was noted by laboratory directors as having been enforced. ${ }^{20}$ Finally, some providers added a third gene to their test, MSH6, but the patent situation for MSH6 is unclear. 


\section{Familial adenomatous polyposis}

One patent, US 5,352,775, covers the $A P C$ gene and was filed by Johns Hopkins in 1994. Again, multiple nonprofit entities and one for-profit provider offer full-sequence testing for FAP as described in Table 1. Finally, Cho et al. ${ }^{20}$ note Johns Hopkins enforced its patent on at least two of the laboratories surveyed in 2001 .

\section{GENETIC TESTS}

\section{Breast cancer}

For patients suspected to have one of the BRCA mutationsbased on strong family history and an early age of onset among cancer-developing family members - two types of genetic testing are available. First, if the patient comes from an ethnic group already known to have specified mutations or a mutation known from another member of that family, several nonprofit university laboratories and one commercial laboratory can perform a targeted genetic test. These tests range in cost from $\$ 325$ to $\$ 2975 .{ }^{28}$ If the patient is not a member of a known risk group or if her physician believes full DNA sequencing analysis is necessary, Myriad Genetic Laboratories is the United States' sole provider of full DNA sequencing for the $B R C A$ genes.

The patent story outside the United States is more complicated and described in a separate case study by Richard Gold and Julia Carbone. ${ }^{34}$ For example, patents have been obtained but the patents are being ignored by provincial health systems in Canada. In Australia and the United Kingdom, Myriad's licensee permitted use by health systems but announced a change of plans in August 2008. (Shobita Parthasarathy provided additional information about Myriad's experience in the United Kingdom. ${ }^{19}$ ) In effect, the United States is the only jurisdiction where Myriad's strong patent position has conferred sole-provider status.

AHRQ reports that the analytic sensitivity and specificity for Myriad's tests are $>99 \% .^{28}$ Myriad's price for "full-sequence analysis," which also includes rearrangement testing, is $\$ 3120$ (Myriad Genetics, personal communication, 2007). Myriad performs redundant testing of each amplicon in both the forward and reverse direction to reduce PCR failure from DNA sequence variants in PCR primers. Myriad resequences any amplicon in which a mutation is detected twice and offers free sequencing of family members to characterize variants of uncertain clinical significance. Finally, when new information is found about a mutation (i.e., an uncertain variant reclassified as a mere polymorphism or as deleterious mutation), Myriad sends an amended report to the ordering physician of every patient in whom this variant has been found. ${ }^{1}$ Myriad performs the same variant characterization services for Lynch syndrome (HNPCC) and FAP testing.

One report in the European Journal of Human Genetics questions the cost-effectiveness of using full-sequence analysis testing as a screening method for at-risk women (defined as women with two first-degree relatives with breast cancer) noting that their "results on genetic testing for breast cancer show that [direct DNA sequencing] is not the most costeffective method available" and that "the monopolist approach of the firm which owns the patents on the [BRCA1 and $B R C A 2]$ genes may, therefore, limit the use of the most cost-effective strategies." 35

\section{Lynch syndrome (HNPCC)}

Several laboratories offer full-sequence analysis for Lynch syndrome, including both nonprofit centers and two commercial laboratories. With the exception of the price listed for
Quest Diagnostics, prices are list prices for insurance companies. Prices were collected in 2008. Unless otherwise noted, prices come from personal communications with the relevant laboratories.

- Baylor: $\$ 1150$ per gene or $\$ 3200$ for the $M L H 1, M S H 2$, and MSH6 genes. ${ }^{36}$

- Boston University: \$2995 for all three genes (MLH1, $\mathrm{MSH} 2$, and MSH6).

- City of Hope: $\$ 1771.20$ for MLH1, $\$ 1474.56$ for $M S H 2$, $\$ 1400.40$ for MSH6.

- Harvard: $\$ 2700$ for all three genes $(M L H 1, M S H 2$, and MSH6). ${ }^{37}$

- Huntington Laboratory: $\$ 1200$ for two genes (MLH1 and MSH2) plus $\$ 600$ for MSH6 (\$1800 for all three genes).

- Mayo Clinic: \$2000 for two genes (MLH1 and MSH2) and $\$ 1100$ for MSH6 (\$3100 for all three genes)

- University of Pennsylvania: $\$ 1360$ for $M L H 1, \$ 740$ for $M S H 2$, and $\$ 740$ for MSH6 (\$2840 for all three genes).

- Quest Diagnostics: \$2940.00 for full sequencing of both MLH1 and MSH2 and \$1820.00 for MSH6 (\$4760 for all three genes).

Among for-profit testing laboratories, Myriad charges $\$ 2950$ for its COLARIS ${ }^{\circledR}$ test, which includes full sequencing of the $M L H 1, M S H 2$, and MSH6 genes and testing for major rearrangements. Rearrangement testing complicates the picture further, as each laboratory has its own price as follows:

- Baylor: Rearrangement testing for either $M L H 1$ or $M S H 2$ is $\$ 625$; rearrangement testing for MSH6 is not available.

- Boston University: Rearrangement testing is included in the cost of \$2995 for sequencing MLH1, MSH2, and MSH6.

- City of Hope: Rearrangement testing and dosage analysis for seven exons in MSH2 is \$547.56; rearrangement testing and dosage analysis for all exons in MSH6 is $\$ 658.80$.

- Harvard: Rearrangement testing for $M L H 1$ or $M S H 2$ is $\$ 600$; rearrangement testing for both is $\$ 800 .{ }^{37}$

- Huntington Laboratory: Rearrangement and gene dosage analysis for both $M L H 1$ and MSH2 is $\$ 600$.

- Mayo: Rearrangement testing is included in the above prices.

- Quest Diagnostics: Rearrangement testing for both $M L H 1$ and MSH2 is \$540.00; rearrangement testing for MSH6 is not available.

A representative of the University of Pennsylvania Medical Center's laboratory stated that rearrangement testing for all of the colon cancer genes discussed here is not available as a listed service but can be done on a research basis. Finally, the reported sensitivity of these tests ranges from $50 \%$ to $70 \% .^{29}$

\section{Familial adenomatous polyposis}

Four nonprofit organizations offer direct DNA sequencing for FAP, as does Myriad Genetics.

- Baylor: \$1675 for full-sequence analysis; \$625 for rearrangement testing. ${ }^{36}$

- Harvard: \$1500 for full-sequence analysis; \$600 for rearrangement testing. ${ }^{38}$

- Huntington Laboratory: \$1200 for full-sequence analysis; $\$ 600$ for gene dosage and rearrangement testing.

- University of Pennsylvania: \$1360 for full-sequence analysis.

- Boston University: \$1675 for full-sequencing analysis; $\$ 495$ for rearrangement testing.

- Mayo Clinic: \$1300 for full sequencing and includes rearrangement testing. 
Among commercial laboratories, Myriad charges \$1795 for its COLARIS AP ${ }^{\circledR}$ test, providing a full-sequence analysis for the $A P C$ gene and major rearrangements and two mutations of $M Y H$. The reported sensitivity for these FAP tests ranges from $80 \%$ to $90 \% .^{29}$

\section{MYH}

In addition to Myriad, four other providers test the MYH gene for cancer-related mutations.

- Baylor: $\$ 1150$ for full-sequence analysis, two mutation analysis for $\$ 300$, no rearrangement testing available.

- Huntington Laboratory: $\$ 600$ for full-sequence analysis, no rearrangement testing available; two mutation analysis available for $\$ 250$.

- University of Pennsylvania: \$500 for full sequencing; targeted mutation for two mutations for $\$ 600$.

- Mayo: \$306.60 testing for two mutations (Baylor College of Medicine, personal communication, 2008).

\section{Summary of costs}

Table 3 notes the approximate sizes of each of the genes discussed above. Table 4 gives the number of amplicons used by Myriad Genetics for its $B R C A$ and hereditary colon cancer tests. The full-sequencing tests are done by choosing PCR primers that flank exons or subsections of exons, amplifying the DNA that spans the relevant exonic sequences, and sequencing those stretches of DNA. The amplicons include the protein-coding regions of the genes, plus a small amount of flanking sequence for each unit. Amplicons may span an entire (short) exon or may break a protein-coding region into segments that can be amplified by PCR (so, long exons are represented by several amplicons). At Myriad Genetics, each amplicon is amplified from two sets of PCR primers, so that each amplicon is sequenced twice. We did not obtain details of laboratory procedure at other testing services, because we did not need to make interlaboratory comparisons.

Table 3 Approximate size of genes

\begin{tabular}{lcr}
\hline Gene & Amplicons $^{a}$ & Size (bp) \\
\hline BRCA1 $^{92}$ & 35 & 81,155 \\
BRCA2 $^{93}$ & 47 & 84,193 \\
APC $^{94}$ & 42 & 108,353 \\
MLH1 $^{95}$ & 19 & 57,359 \\
MSH2 $^{95}$ & 16 & 80,098 \\
MSH6 $^{96}$ & 25 & 23,807 \\
\hline
\end{tabular}

The number of amplicons is based on Myriad Genetics' method of "full-sequence" analysis, based on publicly available data from Myriad's technical specification sheets for its tests and confirmed by phone conversations with Myriad staff. This allows rough comparison of $B R C A$ vs. colon cancer gene tests at Myriad. The amplicons and testing protocols are different from other laboratories, but for those laboratories, the overall cost is the relevant metric. The objective of the table for hereditary colon cancer susceptibility testing is to compare interlaboratory prices for hereditary colon cancer susceptibility, so, overall price is the relevant measure, and per-amplicon cost is merely a rough indicator of marginal price per unit among laboratories. Gene sizes are taken from the National Center for Biotechnology Information database and cross-checked with the Genome Browser, University of California Santa Cruz. Fulllength gene sizes do not reflect the number of bases sequenced in the actual gene tests, because actual genetic tests sequence neither the entire genomic sequence nor the cDNA sequence (with introns edited out) of the genes, but rather "amplicon" fragments of the gene that can be amplified by PCR

aAmplicons used by Myriad for its "full-sequence" analysis.
We use these figures because Myriad, as sole provider of the $B R C A$ test, is the only laboratory for which we can compare prices for $B R C A$ and colon cancer testing. For other laboratories, we assume that they use comparable methodology, although they do not use the same PCR primers, likely use a somewhat different number of amplicons, and may not use exactly the same protocols for testing. The comparisons are, therefore, only rough benchmarks, and the overall price is the main metric. Myriad Genetics is on the high side of pricing for colon cancer testing in overall price (and the only provider for breast cancer testing), but Myriad also includes rearrangement testing and (for FAP and attenuated FAP) tests common mutations in a gene, $M Y H$, which some other laboratories price as separate tests but do not necessarily analyze with the standard FAP full-sequence test. Table 4 uses these gene sizes to determine the approximate total number of base pairs sequenced per genetic test for both breast and ovarian cancers, and colorectal cancers tests, then estimates charge per kilobase (1000 base pairs) for each test as well.

As Table 4 shows, Myriad's charge per amplicon varies over the three tests it offers, ranging from $\$ 38.05$ for its $B R C A 1 / 2$ test, to $\$ 40.80$ for its FAP test, to $\$ 49.17$ for its Lynch syndrome (HNPCC) test. Myriad's charge per amplicon is actually lower for its $B R C A 1 / 2$ tests, which are done under exclusive provider status associated with Myriad's dominant patent position, compared with the colon cancer tests, despite there being multiple providers and lack of dominant patent position for the various hereditary colon cancer susceptibility tests. This shows no clear price premium for the $B R C A$ full-sequence tests.

Myriad's normalized price for colon cancer testing is at the high end for FAP (but that includes two mutations in another gene, $M Y H$, and rearrangement testing) and is in the middle of the range for Lynch syndrome (HNPCC) testing for the three DNA repair genes in that pathway, MLH1, MSH2, and MSH6. All laboratories offering colon cancer testing are presumably paying comparable licensing fees to the patent holders, although the licensing arrangements are not public information; so, we do not know details.

The result is somewhat different if normalization is done on cost "per base pair," rather than per PCR amplicon. Calculated per base pair of the full-length native gene, $B R C A$ testing price is $15-48 \%$ higher than for colon cancer testing ( $\$ 18.87$ per kilobase of gene sequence for $B R C A 1$ and 2, compared with $\$ 16.57$ for $A P C$, and $\$ 12.71$ for the $M L H 1, M S H 2$, and MSH6 test). However, the "length of gene" basis for normalization is not as relevant for normalization, because the test is done by sequencing gene fragments as PCR amplicons, and the unit cost is more related to number of amplicons than total gene size. The price comparisons may be surprising to some, as normalized prices show little if any price premium. This, in turn, suggests the main market impact of the $B R C A$ patents is not on price but rather on volume, by directing $B R C A$ full-sequence testing in the United States to Myriad, the sole provider.

\section{Limitations on price comparison}

The comparison of BRCA and FAP/HNPCC testing is confounded by several variables that are not controlled, so, it is inexact. Different laboratories use somewhat different methods and different numbers of amplicons, and different degrees of testing for insertions, deletions, and rearrangements. FAP and HNPCC genes do have patents on them, and prices may include licensing fees, hence, this is not a "patented versus nonpatented gene" pricing comparison. The rearrangement testing is included in total prices, but the details of those aspects of testing differ between $B R C A$ and colon cancer predisposition mutations. The data cannot rule out a monopoly price effect but only suggest that any such effect is buried in the confounding variables. One other powerful constraint 
Table 4 Comparison of cost per bp among genetic tests

\begin{tabular}{|c|c|c|c|c|c|}
\hline Disease & Genetic test & Total amplicons & Test provider & $\begin{array}{l}\text { Provider's } \\
\text { charge }(\$)\end{array}$ & $\begin{array}{l}\text { Charge per } \\
\text { amplicon }(\$)\end{array}$ \\
\hline Breast/ovarian cancer & $\begin{array}{l}B R C A 1 \text { and } B R C A 2 \text { full } \\
\text { sequencing }\end{array}$ & $35+47=82$ & $\operatorname{Myriad}^{a}$ & 3120 & 38.05 \\
\hline \multirow[t]{7}{*}{ FAP } & \multirow[t]{7}{*}{$A P C$ full sequencing } & \multirow[t]{7}{*}{42} & Baylor & 1675 & 39.88 \\
\hline & & & Boston & 1675 & 39.88 \\
\hline & & & Harvard & 1500 & 35.71 \\
\hline & & & Huntington & 1200 & 28.57 \\
\hline & & & University of PA & 1360 & 32.38 \\
\hline & & & Mayo Clinic & 1300 & 30.95 \\
\hline & & & Myriad $^{b}$ (44 amplicons) & 1795 & 40.80 \\
\hline \multirow[t]{9}{*}{ Lynch syndrome (HNPCC) } & \multirow{9}{*}{$\begin{array}{l}M L H 1, M S H 2, \text { and } M S H 6 \\
\quad \text { full sequencing }\end{array}$} & \multirow[t]{9}{*}{$19+16+25=60$} & Baylor & 3200 & 53.33 \\
\hline & & & Boston University & 2995 & 49.92 \\
\hline & & & City of Hope & 4646.16 & 77.44 \\
\hline & & & Harvard & 2700 & 45.00 \\
\hline & & & Huntington & 1800 & 30.00 \\
\hline & & & Mayo Clinic $^{c}$ & 3100 & 51.67 \\
\hline & & & Myriad $^{c}$ & 2950 & 49.17 \\
\hline & & & University of PA & 2840 & 47.33 \\
\hline & & & Quest Diagnostics & 4760 & 79.33 \\
\hline \multicolumn{6}{|c|}{$\begin{array}{l}\text { Cost per bp represents authors' calculations based on costs reported by the testing facilities and the size of each gene as reported by NCBI. } \\
{ }^{a} \text { Includes major rearrangement testing ( } 5 \text { common insertions/deletions and analysis for any other rearrangements in high-risk individuals). } \\
\text { 'Includes Southern Blot analysis for rearrangements and } 2 \mathrm{MYH} \text { mutations (an additional } 2 \text { PCR amplicons) with full sequence of MYH if one of the } 2 \text { common mutations } \\
\text { is detected. } \\
{ }^{c} \text { Includes rearrangement analysis. }\end{array}$} \\
\hline
\end{tabular}

on pricing is reimbursement practices for genetic tests, which tend to start from per-amplicon unit prices and are negotiated for specific tests from that baseline.

\section{CURRENT GENETIC TESTING GUIDELINES}

\section{Breast cancer}

Although in 2005, the United States Preventative Services Task Force (USPSTF) recommended against routine genetic testing for the $B R C A 1 / B R C A 2$ mutations, the USPSTF does recommend testing for women whose family histories suggest $B R C A 1$ or $B R C A 2$ risk. ${ }^{39}$ Specifically, the USPSTF recommends that women with family histories suggestive of $B R C A 1 / B R C A 2$ mutations be referred for appropriate genetic counseling because "the benefits of referring women with an increased-risk family history to suitably trained health care providers outweigh the harms." 39

In terms of clinical algorithms, the NCCN publishes and maintains guidelines on its Web site http://www.nccn.org/.

\section{Colorectal cancer}

The Evaluation of Genomic Applications in Practice and Prevention Working Group (EGAPP) published recommendations for genetic testing among newly diagnosed individuals with colorectal cancer. ${ }^{7}$ They examined four genetic testing strategies and found no decisive winner. All four protocols involve genetic testing, but the methods, cost, and selection criteria for which patients get which kind of test differ. The most expensive but also most sensitive method is full-sequence testing, the pathway most comparable with Myriad's BRCA testing. The EGAPP recommendations are based on a January 2009 supplementary evidence review. ${ }^{8}$ That review, in turn, builds on a massive 2007 evidence review by the Tufts-New England Medical Center Evidence-Based Practice Center. ${ }^{40}$ The NCCN has published its clinical guidelines on testing for FAP and HNPCC. And, a joint committee of the ACS, the US Multi-Society Task Force on Colorectal Cancer (MSTFCRC) and the American College of Radiology (ACR; ACS/MSTFCRC/ ACR) produced a consensus statement on screening and surveillance for colorectal cancer and polyps in May 2008.41

New EGAPP analysis, in addition to sifting through evidence and assessing four genetic testing strategies, also shifts the framework for genetic testing away from family history and toward genetic testing of those newly diagnosed with colorectal cancer. This is a significant change, indicating the many individuals who do not know about cancer in relatives or when they are the first individuals in their families identified with the mutations that can now be identified as conferring risk. That is, clinical practice appears to be shifting from genetic testing only when family risk is evident to using genetic testing to identify new individuals and families at risk. This is mainly because many individuals carrying mutations will be missed if family history is a threshold criterion for testing. It is worth noting that if genetic testing becomes less expensive and more widely available and as more mutations associated with cancer risk are identified, DNA analysis could move 
higher up the clinical decision tree, not just in Lynch syndrome but in other cancers as well.

NCCN guidelines specify the following inclusion criteria to consider genetic testing for any of the various inherited colorectal cancers:

- Early-onset colorectal cancer (age $<50$ years), or

- Clustering of same or related cancer in close relative, or

- Multiple colorectal carcinomas or $>10$ adenomas in the same individual, or

- Known family history of hereditary cancer syndrome with or without mutation. ${ }^{42}$

From here, the NCCN guidelines split between FAP and HNPCC.

\section{Familial adenomatous polyposis}

In patients with the FAP phenotype ( $>100$ colorectal polyps), genetic testing is recommended to establish the diagnosis. From there, the NCCN recommends:

Genetic testing in individuals with familial polyposis should be considered before or at the age of screening. The age for beginning screening should be based on the patient's symptoms, family phenotype, and other individual considerations. ${ }^{42}$

In the event that a familial mutation is unknown, the NCCN further recommends:

In some families, APC mutations cannot be found with available testing technology, recognizing that the sensitivity to identify APC mutations is currently only about $80 \%$. In other families, affected individuals have died or are not immediately available. Under these circumstances, APC testing should be considered for at-risk family member. If the mutation responsible for FAP within a family is not found, it is important to remember the limitations of interpreting a gene test in a presymptomatic individual. Evaluating presymptomatic individuals at risk in these families presents a difficult problem, since the mutation responsible for FAP within the family is not known. Certainly, a positive test in a presymptomatic person is informative even when the familial mutation has not been previously identified. But, interpreting a test in which "no mutation is found" in a presymptomatic person is not the same as a "negative test." 42

The ACS/MSTFCRC/ACR guideline identifies those with a genetic diagnosis of FAP or suspected FAP without genetic testing as "high risk" and recommends considering genetic testing (if not already done). It recommends monitoring starting age as 10-12 years, with an annual flexible sigmoidoscopy examination. If genetic testing is positive, "colectomy should be considered." 41

\section{HNPCC}

The NCCN recommends HNPCC genetic testing only for certain patients:

- Individuals in families meeting either the Amsterdam I or II criteria, and

- Affected individuals meeting Revised Bethesda guidelines. ${ }^{42}$
The 2008 ACS/MSTFCRC/ACR guideline recommends offering genetic testing for all first-degree relatives of a confirmed case. Monitoring for those with confirmed or at increased risk of HNPCC should begin at age 20-25 years or a decade before the youngest case in a family (whichever is younger), with colonoscopy every $1-2$ years. ${ }^{42}$

The 2007 Tufts Evidence-Based Practice Center report noted a major gap in knowledge about how best to do the genetic testing and differing views on test algorithms in the literature. The report also noted that sequencing was the "method of choice" for mutation detection, but with many different technologies for doing such sequencing and a need to supplement it with rearrangements/insertion/deletion testing. No clear, consistent "winner" was found among technologies.

Regarding test utility, the report concluded:

Pretest genetic counseling had good efficacy in improving knowledge about HNPCC and resulted in a high likelihood of proceeding with genetic testing, satisfaction in the decision to undergo genetic testing, and decreasing depression and distress levels among family members of HNPCC probands with cancer and among asymptomatic individuals from HNPCC families.

Identification of HNPCC mutations was associated with an increase in the likelihood that family members of probands with $\mathrm{CRC}$ [colorectal cancer] would undergo cancer-screening procedures. HNPCC family members who underwent cancer-screening procedures had a lower risk of developing HNPCC-related cancers and lower mortality rates than those who did not take actions. ${ }^{40}$

These conclusions will now be updated by the January 2009 EGAPP recommendations, which do not choose among the four genetic testing strategies, but do recommend genetic testing in newly diagnosed colorectal cancer. ${ }^{7}$ The trend seems to be moving toward genetic testing earlier in the diagnostic process to guide treatment and to identify others in families who might be at risk but do not know it.

If a tumor sample is available, the NCCN recommends testing for both immunohistochemistry and microsatellite stability testing first rather than beginning with DNA sequencing. The results of either of these preliminary tests can direct a clinician to the appropriate gene to sequence for "germline analysis," thus avoiding the shotgun-like approach of a fullsequence analysis on all three genes. ${ }^{7}$

\section{NONGENETIC SCREENING OPTIONS}

\section{Breast cancer}

In 2002, the USPSTF recommended mammography for all women once every $1-2$ years after the age of 40 years. ${ }^{43}$ AHRQ reports that the Cancer Genetic Studies Consortium recommended annual mammography for women beginning between the ages of 25 and 35 years, with annual clinical breast examinations also beginning between ages 25 and 35 years and monthly self breast examinations beginning between ages 18 and 21 years. ${ }^{28}$ AHRQ also notes that the USPSTF does not currently recommend screening women at any age for ovarian cancer. ${ }^{28}$ The ACS issued guidelines in April 2007 calling for magnetic resonance imaging screening, in addition to mammography, for women carrying $B R C A$ mutations and first-degree relatives of those with $B R C A$ mutations. ${ }^{44}$ 


\section{Colorectal cancer}

Beginning at the age of 50 years, the ACS recommends:

- Fecal occult blood testing (FOBT) annually, or

- Flexible sigmoidoscopy every 5 years, or

- Annual FOBT plus flexible sigmoidoscopy every 5 years, or

- A double-contrast barium enema every 5 years, or

- A colonoscopy every 10 years. ${ }^{26}$

However, according to the USPSTF:

The USPSTF found good evidence that periodic FOBT reduces mortality from colorectal cancer and fair evidence that sigmoidoscopy alone or in combination with FOBT reduces mortality. The USPSTF did not find direct evidence that screening colonoscopy is effective in reducing colorectal cancer mortality; efficacy of colonoscopy is supported by its integral role in trials of FOBT, extrapolation from sigmoidoscopy studies, limited case-control evidence, and the ability of colonoscopy to inspect the proximal colon. Double-contrast barium enema offers an alternative means of whole bowel examination, but it is less sensitive than colonoscopy, and there is no direct evidence that it is effective in reducing mortality rates. ${ }^{45}$

\section{INTERPRETING TEST RESULTS/OPTIONS FOR PROPHYLACTIC TREATMENT}

\section{Breast and ovarian cancer}

The clinical utility of $B R C A 1$ and $B R C A 2$ screening may be summarized as follows:

- For those testing positive, there are cost-effective approaches to chemoprevention (prophylactic tamoxifen for breast cancer and oral contraceptives for ovarian cancer), screening, and surgery (prophylactic mastectomy, prophylactic salpingo-oophorectomy or tubal ligation), all of which result in gains in both life expectancy and quality adjusted life years (QALYs) relative to watchful waiting. ${ }^{46}$

- For high-risk patients who test negative, there may be reduced anxiety about the future risks of breast or ovarian cancer. These gains must be balanced against the losses experienced by those who test positive, including elevated anxiety, depression, and guilt. ${ }^{47}$

- Finally, although $\$ 50,000$ per QALY is the conventional benchmark for cost-effectiveness analysis, ${ }^{48}$ some authors do argue for a standard of $\$ 100,000-150,000$ per QALY. ${ }^{49,50}$

According to AHRQ, interpretation of the test results for $B R C A 1$ and BRCA2 genetic testing can be difficult. For example, if a patient with known positive family history for a specific mutation tests negative, she can be "reassured about her inherited risk." On the other hand, a negative test is "less useful if her relatives have cancer but no detected deleterious mutations." Finally, AHRQ noted that up to $13 \%$ of tests produce results of "uncertain clinical significance." 28 More recent (2008) data are that variants of uncertain clinical significance are found in fewer than $6 \%$ of cases (with the highest rate of "variants of unknown significance" among African Americans, at 11\%). ${ }^{51}$ The crucial data are, "Overall, the VUS [variants of unknown significance] rate decreased from $12.8 \%$ in 2002 to $5.9 \%$ in 2006 , a $54 \%$ reduction, including decreases of $50.1 \%$ (Western European), 58.3\% (African), and 48.6\% (Asian). From 2006 to 2008 the identification of variants of uncertain significance continued to decline to $5.1 \%$ of tests performed. This continued decrease was observed in all ethnic groups, with the largest decline in the African American population where the VUS rate declined from $38.6 \%$ in 2002 to $10.9 \%$ in $2008 . " 51$

When women do test positive, the USPSTF first noted in 2002 that women at high risk for breast cancer should consider taking chemoprevention (e.g., tamoxifen) ${ }^{52}$ but then noted in 2005 that there is "insufficient evidence to determine the benefits of chemoprevention or intensive screening in improving health outcomes." 39 The ACS recommends that women positive for $B R C A 1 / B R C A 2$ mutations consider tamoxifen therapy. ${ }^{27}$ See Table 5 for a breakdown of the results found in three different cost-effectiveness studies on chemoprevention in at-risk women.

Surgical options. Both the ACS and the USPSTF note that prophylactic surgery (e.g., bilateral mastectomy and bilateral oophorectomy) significantly decreases the chances of developing cancer in $B R C A$ mutation-positive women and should be strongly considered. ${ }^{27,39}$ Table 6 shows the results from two cost-effectiveness studies on prophylactic surgery. For a complete cost-effectiveness analysis of all preventative strategies surrounding positive $B R C A$ findings, see Anderson et al..$^{53}$

\section{Colon cancer}

According to the American Gastroenterological Association (AGA), patients with Lynch syndrome should receive subtotal colectomy (removal of almost the entire colon, sparing the rectum) with ileorectal anastomosis. This surgical method can preserve some bowel function by fusing the small intestine to the rectum and creating a "pouch" out of small intestine. Thus, patients should not require a permanent colostomy. The AGA recommends the same surgical approach for patients with Lynch syndrome, both those who already have colon cancer and those who are positive for a mutation but have yet to develop any detectable colon tumors or known symptoms. After surgery, patients should still be followed up with regular rectal screening for additional rectal polyps. ${ }^{54}$

We were unable to find cost-effectiveness studies of prophylactic colectomy, but two decision analyses have been published on clinical effectiveness. The first article was published in Gastroenterology in 1996 and demonstrated that compared with

Table 5 Cost-effectiveness studies comparing chemoprevention with surveillance alone

\begin{tabular}{|c|c|c|}
\hline Study & Context & Results (cost per QALY) \\
\hline \multirow{3}{*}{$\begin{array}{l}\text { Grann } \\
\text { et al. } .^{97}\end{array}$} & \multirow[t]{3}{*}{ Positive $B R C A$ test } & 30 -year-old women $=\$ 990$ \\
\hline & & 40 -year-old women $=\$ 1,800$ \\
\hline & & 50 -year-old women $=\$ 3,600$ \\
\hline \multirow{3}{*}{$\begin{array}{l}\text { Hershman } \\
\text { et al. }{ }^{98}\end{array}$} & \multirow{3}{*}{$\begin{array}{c}\text { Two or more first- } \\
\text { degree relatives } \\
\text { diagnosed with } \\
\text { breast cancer }\end{array}$} & 30 -year-old women $=\$ 45,000$ \\
\hline & & 50 -year-old women $=\$ 89,000$ \\
\hline & & 60 -year-old women $=\$ 140,000$ \\
\hline \multirow[t]{3}{*}{$\begin{array}{l}\text { Eckermann } \\
\quad \text { et al. }{ }^{99}\end{array}$} & \multirow{3}{*}{$\begin{array}{l}\text { Hypothetical } \\
\text { cohort of } \\
\text { healthy women } \\
\text { at high risk of } \\
\text { breast cancer }\end{array}$} & $\begin{array}{l}5 \mathrm{yr} \text { of tamoxifen } / 5 \mathrm{yr} \text { of } \\
\text { benefit }=\$ 32,000\end{array}$ \\
\hline & & $\begin{array}{l}5 \mathrm{yr} \text { of tamoxifen } / 10 \mathrm{yr} \text { of } \\
\text { benefit }=\$ 16,000\end{array}$ \\
\hline & & $\begin{array}{l}5 \mathrm{yr} \text { of tamoxifen } / \text { no reduced } \\
\text { incidence at } 10 \mathrm{yr}= \\
\$ 170,000\end{array}$ \\
\hline
\end{tabular}


Table 6 Cost-effectiveness studies comparing prophylactic surgery with surveillance alone

\begin{tabular}{|c|c|c|}
\hline Study & Context & Results (cost per QALY) \\
\hline Grann et al. ${ }^{100}$ & $\begin{array}{l}\text { Positive } B R C A \text { test in } 30 \text {-year-old } \\
\text { women at high risk }\end{array}$ & $\begin{array}{l}\text { Prophylactic oophorectomy and mastectomy }=\text { dominated } \\
\text { prophylactic oophorectomy }=\$ 5,600\end{array}$ \\
\hline \multirow[t]{11}{*}{ Tengs et al. ${ }^{101}$} & \multirow{11}{*}{$\begin{array}{l}\text { High-risk } 30 \text {-year-old women assuming } \\
\text { varying risks of mutation }\end{array}$} & $B R C A$ testing then oophorectomy if positive by mutation probability \\
\hline & & High risk \\
\hline & & $B R C A 1(P=0.5)$ and $B R C A 2(P=0.0)=\$ 3,900$ \\
\hline & & $\operatorname{BRCA1}(P=0.25)$ and $\operatorname{BRCA2}(P=25)=\$ 4,700$ \\
\hline & & $B R C A 1(P=0.0)$ and $B R C A 2(P=0.5)=\$ 5,400$ \\
\hline & & Moderate risk \\
\hline & & $\operatorname{BRCA1}(P=0.1)$ and $\operatorname{BRCA2}(P=0.1)=\$ 17,000$ \\
\hline & & Slight risk \\
\hline & & $\operatorname{BRCA1}(P=0.05)$ and $\operatorname{BRCA2}(P=0.05)=\$ 42,000$ \\
\hline & & Average risk \\
\hline & & $B R C A 1(P=0.0006)$ and $\operatorname{BRCA2}(P=0.0002)=\$ 1,600,000$ \\
\hline
\end{tabular}

"Dominated" means that prophylactic mastectomy and oophorectomy in the Grann et al. article actually saved money compared with surveillance alone.

a colonoscopic surveillance program, prophylactic colectomy for a 40-year-old man with positive HNPCC mutation yields a life expectancy benefit of 8 months to 1.5 years. For a 30 -year old man with positive HNPCC mutation, this benefit increased to between 1 and 2 years. ${ }^{55}$ However, the authors did not analyze quality of life and did not analyze the subtotal colectomy option.

The second clinical effectiveness article was published in the Annals of Internal Medicine in 1998 and addressed both life expectancy and quality of life. This article demonstrated that immediate prophylactic surgery (e.g., either total proctocolectomy or subtotal colectomy) extended overall life expectancy compared with surveillance alone (defined as "colonoscopy every 3 years if no surgical intervention had been performed and flexible sigmoidoscopy of the remaining rectal segment every 3 years after subtotal colectomy" plus segmental resection if cancer was found) in a hypothetical cohort of 25 year olds with HNPCC mutations. ${ }^{56}$ However, in terms of QALYs, both methods of prophylactic surgery actually fared worse than surveillance:

Surveillance leads to the greatest quality-adjusted life expectancy compared with all colectomy strategies. Surveillance led to a gain of 14.0 QALYs compared with no surveillance, 3.1 QALYs compared with immediate proctocolectomy, and 0.3 QALYs compared with immediate subtotal colectomy. Incorporation of quality adjustments resulted in greater quality-adjusted life expectancies for all subtotal colectomy strategies compared with proctocolectomy strategies, with benefit ranging from 0.3 QALYs if colectomy was performed when colorectal cancer was diagnosed to 2.8 QALYs if colectomy was performed at 25 years of age. ${ }^{56}$

For FAP, the AGA recommends that patients who are positive for FAP receive immediate total proctocolectomy (removal of the colon and rectum) to minimize the potential for malignancy except in certain "lifestyle" choices. For example, the
AGA would accept delaying surgery in teenagers with minimally concerning polyps (small and nonvillous) to accommodate employment and academic commitments. ${ }^{57}$ Appropriate follow-up should include endoscopic monitoring of any remaining colon (e.g., if a subtotal colectomy is performed) every 6 months and additional endoscopic monitoring of the upper gastrointestinal tract with biopsies (including the stomach and small intestine) every 6 months to 4 years. ${ }^{57}$ In contrast, the guidelines state that the "use of chemoprevention as primary therapy for colorectal polyposis is not proven and is not recommended." 57

\section{LESSONS LEARNED}

This comparison was selected because it provides a natural case study to compare for-profit testing and exclusive licensing practices for $B R C A$ versus a mix of for-profit and nonprofit patenting with nonexclusive licensing practices for colon cancer susceptibility genes. By using the conceptual framework developed for a parallel literature synthesis, we now consider what lessons might be learned from this case.

For both breast cancer and colon cancer, the genetic tests discussed above have two major implications. First, genetic tests can distinguish genetic (and, thus, inheritable) susceptibility from nongenetic cancers in the original patient. Thus, if the original patient tests positive, then other family members can then test themselves and know with relative certainty whether or not they have inherited the same mutation as their cancersuffering relative. Second, $B R C A$ and colon cancer genetic tests guide treatment decisions for the original patient and alert relatives that they may also be at risk (and can be tested for the same mutation at much lower cost and with greater specificity) as well.

\section{Basic research}

As of August 2008, Myriad has submitted $>18,000$ entries ( $>80 \%$ of total entries) for $>2,600$ unique mutations to the Breast Cancer Information Core (http://research.nhgri.nih.gov/ 
bic) database. As of February 2005, $>4,300$ follow-up publications on $B R C A 1$ and $B R C A 2$ resulted from $>100$ collaborations between Myriad and independent investigators (W. Rusconi, Vice President of Marketing, Myriad Genetics Laboratories, personal communication, 2008). ${ }^{1}$ A search of the Breast Cancer Information Core for mutations catalogued as deposited by Myriad Genetics as of September 25, 2008, revealed 8,826 mutations in BRCA1 and 9,891 mutations in $B R C A 2 .^{2}$ Patent rights are much narrower in Europe. Europe also differs because several countries have explicit research exemptions and diagnostic use exemptions from patent infringement liability that would cover clinical research testing in several European countries. Research and, in some countries, genetic testing also, have, therefore, proceeded in Europe with less concern about patent infringement. (See Text box for more details.)

Some argue that even in the United States, Myriad's definition of infringing research is too broad. Specifically, in 1998 Myriad asserted that even though GDL limited testing to patients in NCI research protocols, GDL was performing a patentinfringing third-party service in which it charged other laboratories and rendered clinical services. As Parthasarathy summarizes Myriad's reasoning, "So long as GDL disclosed results to the patient, [it provided] a commercial service and violat[ed] the patent." 3 The $1999 \mathrm{NCI} /$ Myriad MOU established ground rules permitting use of $B R C A$ testing within a research institution and discounted testing for research clinical testing contracted to Myriad. ${ }^{4}$

According to a 2005 Lewin Group Report published for AdvaMed:

An unintended effect of patents is that they may slow further innovation by blocking R\&D efforts along avenues patented by other companies. This was the case with genetic testing for the BRCA1 and BRCA2 genes [mutations], the presence of which are [is] associated with an elevated risk for developing breast or ovarian cancer. The US Patent and Trademark Office issued patent rights for $B R C A 1$ and $B R C A 2$ to a privately owned diagnostics firm. These rights included the gene sequences and any resulting applications developed from them, including laboratory tests and targeted drug therapies. The patents allow the firm to control breast cancer susceptibility testing and research. ${ }^{5}$

Although the Lewin Group concluded that Myriad's exclusive patents on the $B R C A$ genes stifled further basic research based on this theory, we found few data either to support or to refute this conclusion. The Gold and Carbone ${ }^{34}$ case study did identify a decision not to report some $B R C A$ mutation analysis by Canadian researchers. Specifically, at a November 2006 workshop at Edmonton, researchers from a Canadian university reported that they had refrained from reporting $B R C A$ testing results to the public database because they had been advised by their university's general counsel that it could alert Myriad to infringing activity. The researchers were cautioned not to leave a public trace that they had done $B R C A$ testing without a license, and this meant they did not contribute their research results to the appropriate public database despite their results being of general interest.

Myriad maintains it has never enforced its patents against researchers and does not enforce its patents against laboratories providing $B R C A$ testing services in a form it does not do itself (such as PGD and real-time PCR of DNA amplified from paraffin-embedded tissues). Myriad notes it permitted rearrangement testing and even referred patients to Mary-Claire King and others until it began to offer such testing itself. Myriad says it has never even threatened to take action against basic researchers or those doing preimplantation diagnostic testing.

A chilling effect, however, does not take hold only when each and every instance of potential infringement is the subject of patent enforcement. Moreover, Myriad never publicly stated its de facto research use exemption policy. Myriad either passed on an opportunity to demonstrate its intentions publicly in written form or avoided comment to keep legal options open. And keeping options open equates to a chilling effect in zones of uncertainty. Myriad, therefore, cannot fully elude responsibility for any chilling effect on research, because the company could fully anticipate that others would refrain from research for fear of being sued for infringement. Requesting "simple notification" to Myriad is not a full remedy, as it requires notifying the very party that might, at its option, take legal action once alerted. That is, for Myriad to make credible claims of being fully supportive of unfettered research, it would need to express that policy in a form that could be the basis for others' actions and not passively rely on others to ask them for permission. Other laboratories would need to know what activities Myriad would and would not pursue as infringement, specified in a way that courts could interpret. Ambiguity may itself stifle basic or clinical research as researchers either avoid the work altogether or are wary of publicly reporting results.

We have not found similar evidence of a chilling effect in the basic science arena for either FAP or HNPCC. This may be because of three related features: first, lack of enforcement actions, second, patent holders are academic institutions, and third, licenses are nonexclusive.

\section{Development}

The Lewin report concluded that Myriad's patents "also were found to affect development and provision of potentially more cost-effective testing strategies." 5 More specifically, a French study found that:

...there exist alternative strategies for performing $B R C A 1$ diagnosis: prescreening techniques such as FAMA [fluorescent assisted mismatch analysis] and, potentially, DHPLC [denaturing high performance liquid chromatography] or DGGE [denaturing gradient gel electrophoresis], based on the current estimates of their sensitivity, would minimize the cost of diagnosis while also ensuring a comparable level of effectiveness to that of applying DS [direct sequencing of the whole genomic DNA] to the entire gene. ${ }^{6}$

When compared with the most cost-effective mutation detection strategy analyzed (in common use in French testing laboratories), the average cost per mutation detected using the Myriad approach was five times as high. ${ }^{6}$ That is, leaving aside the issue of pricing, the costs entailed-including consumable supplies, equipment, and personnel-to perform the Myriad approach was much higher than alternative approaches that had been developed and were in use in Europe. This criticism suggests that Myriad has eschewed cheaper testing methods because as a monopoly provider it has little incentive to support them. It is difficult to judge this assertion. The comparison with colon cancer genetic testing suggests, however, that, first, Myriad is well within range in its pricing of colon cancer tests compared with other providers and, second, its cost per unit for 
$B R C A$ testing is in the same range as colon cancer testing and, if anything, a bit less expensive. Moreover, the analysis of genetic testing strategies has low-cost and high-cost options analogous to $B R C A$ testing, and it is not clear which strategy is optimal. ${ }^{7,8}$

The technologies for testing are not qualitatively different among these different genes, so, if Myriad has failed to shift to cheaper testing technology, then so have other providers for comparable colon cancer tests. Both $B R C A$ and colon cancer susceptibility genes are large and complex, and there are hundreds of documented mutations in them that cannot be predicted in advance except in subpopulations (such as Ashkenazim).

The pricing data do not address whether early resort to full-sequence testing in high-risk families is optimal for a health system. Myriad believes it is, and in the United States with Myriad as sole provider, this becomes policy de facto. In other countries, Myriad can still supply full-sequence testing, but health systems may adopt testing algorithms that resort to full-sequence testing later in the process and use other tests as screens. Myriad's patent position in effect allowed it to establish the standard of care in the United States, but in other countries it did not.

Those in human genetics and cancer also tell about the patent race between Johns Hopkins University and Oregon Health Sciences University-Dana Farber Cancer Institute for the HNPCC gene MLH1. Both Oregon Health Sciences and Johns Hopkins hold patents claiming MLH1. The Oregon patent is shared with Dana Farber. It was filed December 9, 1994, and was issued as US 6,191,268 on February 20, 2001 (Oregon Health Sciences and Johns Hopkins later filed two method patents as well). The Johns Hopkins patent, on the other hand, is shared with the for-profit firm Human Genome Sciences. The Hopkins/Human Genome Sciences patent application was filed on June 6, 1995, and issued as US 6,610,477 on August 26, 2003. Although the details of this race do not appear in the literature, clearly patenting and ultimately test development played a role in the search for MLH1 as Johns Hopkins ultimately partnered with a for-profit corporation to complete its work.

Dr. Merz notes the additional concern that Myriad's patents could allow it to collect license royalties as new mutations are sequentially patented, in effect extending the patent term. Dr. Merz writes that:

Think of it this way: new mutations are continually being found in the BRCA1 and BRCA2 genes. Assuming that patent applications are continually being filed on them, then the patent holders may have an effective monopoly on testing for the period extending from the grant of the first patent for the first discovered mutation until the end of the patent term on the last discovered mutation. If the patentee were to license the patents, royalties could only be collected for the term of each individual patent (the courts would invalidate attempts to extend the patent term by contract or to tie licenses of the patented and off-patent tests). Thus, by monopolizing the testing service, the patentee undermines the time limitation on the grant of monopoly. ${ }^{58}$

Another critique of patenting centers on reduced incentives of a monopoly provider to introduce newer, cheaper, or otherwise better alternative tests. For example, there is an alternative diagnostic technique to $B R C A$ called MLPA, a molecular way to detect genetic variations, including $B R C A 1$ and $B R C A 2$ mutations, under development at University of Washington. ${ }^{59}$ Using MLPA, a 2006 study published in the JAMA found that Myriad's testing strategy missed up to $12 \%$ of large genomic deletions or duplications. ${ }^{9}$ The authors noted that the missed mutations were not because of a technical error in Myriad's testing but a flaw in the testing strategy. That is, the rearrangements were missed not because of sequencing errors in the amplicons, but because sequencing fragments of $B R C A$ as amplicons did not detect large-scale chromosome rearrangements and deletions. The article noted "many mutations are inherently not detectable by short-range PCR followed by genomic sequencing." "9 Drs. Grodman and Chung state in their testimony before the House Subcommittee on Intellectual Property that this testing deficit was only corrected after "considerable pressure from the scientific community,"10,11 but Myriad notes it began testing for the five most common rearrangements (accounting for about a third of all rearrangements) in 2002 and would have detected one third of those the JAMA article reported as missing - and simultaneously began developing a test for large rearrangements $\left(\right.$ BART $^{\circledR}$ ), which it launched in August 2006 for the higher risk patients (similar to the JAMA article's criteria) as part of BRACAnalysis ${ }^{\circledR}$. Myriad's claim that it was already working on $\mathrm{BART}^{\circledR}$ before the JAMA article appeared is corroborated by poster presentations on large-scale rearrangement testing in 2004, a chronology that does not fit with the characterization of Myriad responding "under considerable pressure" only after the JAMA article. The JAMA publication no doubt accelerated Myriad's efforts to introduce the new BART ${ }^{\circledR}$ test, however, as indicated by Myriad's Clinical Update of September $2006.12,14,60$

In her written statement to the House Judiciary Committee, Dr. Chung noted that she believed, "In a competitive marketplace, this delay would have never occurred."11 Myriad does not agree, and asks: "Could a cost-effective, high throughput, scientifically valid assay be designed and used clinically? It must be noted that the MLPA kits are not FDA approved and are labeled for research use only." 61

Rearrangements are also common in colon cancer susceptibility genes and are included as part of such testing at Myriad and many other laboratories. However, we found no literature about a major controversy among test providers for colon cancer comparable with the very public brouhaha over breast/ ovarian genetic testing.

Dr. Chung's written statement for the October 30 House Judiciary hearing states that Myriad's decision not to test paraffin-embedded tissue has hampered availability of that type of testing in instances where it might be clinically useful. ${ }^{11}$ According to Myriad's technical specifications sheet available online, Myriad isolates only the white blood cells from each sample to extract and purify DNA for testing. ${ }^{62}$ Without market pressure to innovate, Dr. Chung notes that Myriad has little incentive to develop techniques to analyze samples other than blood samples, thereby "leaving families at risk with no remedy." 11 Myriad responds that it refers such cases to known testing services with relevant technical capacity when it learns of instances where such testing is needed. And, it notes that in most cases where paraffin-embedded testing is relevant, the living person (or persons) at risk could be directly tested using full-sequence analysis, followed by mutation-specific testing for others in the family. Myriad states it has never enforced its patents against a provider offering testing in a form Myriad does not offer itself, such as preimplantation diagnosis, prenatal diagnosis, or real-time PCR of paraffin-embedded tissue sam- 
ples. $^{1}$ The implication is that Myriad would not enforce its patents in such circumstances, although again, as in research, there is no public written statement of that policy. Myriad has licensed three laboratories to perform preimplantation diagnosis, for example. ${ }^{16}$ Although this may be a policy, we did not find a public statement to this effect on Myriad's Web site (indeed it took some digging to find this information). Thus, individuals likely would not know about this policy unless they contacted Myriad, thereby alerting them of their intention to test and alerting Myriad of the option of taking legal action to prevent patent infringement.

Finally, the US FDA has also approved an investigational device exemption study for a breast cancer risk test developed by InterGenetics called OncoVue ${ }^{\circledR}$. Billed as "the next-generation genetic breast cancer risk test," OncoVue reports that it is "the nation's first genetic-based breast cancer risk test to undergo the FDA approval process."63 Opaldia plans to release OncoVue in the United Kingdom and Ireland under an exclusive agreement. ${ }^{64}$

These are not isolated counter examples: AHRQ estimated that for all three areas of cancer included in this case study, there are more genetic tests for cancer in the pipeline than are currently available. Although we cannot be certain of what this picture would have looked like absent patents, it appears that gene patents notwithstanding, the genetic testing for inherited risk of cancer is moving in the direction of an even more bountiful range of clinical genetic tests. (See Table 7, Summary of clinical genetic tests.)

The foregoing also is a reminder that patent protection never guarantees permanent protection from competition. It remains to be seen whether these developments culminate in Myriad having to reduce its price or relax its licensing well before its patent expires and to offer new testing modalities. And, the same competitive effects may enter colon cancer genetic testing, for which there is no single provider with a dominant patent position.

$B R C A$ and colon cancer genes also differ in measures of patent enforcement activity. Dr. Cho et al.'s ${ }^{20} 2003$ survey of laboratory directors demonstrates nine instances of patent enforcement by Myriad Genetics on its BRCA patents; by comparison, Johns Hopkins enforced its $A P C$ patent for FAP genetic testing twice, and no laboratory directors reported enforcement of the HNPCC patents.

In an article reviewing litigation over US gene patents, Christopher Holman found 31 total cases of litigation (covering an estimated $1 \%$ of gene patents). Two of those cases centered on $B R C A$ patents, compared with none for patents associated with

Table 7 Summary of clinical genetic tests

\begin{tabular}{lccc}
\hline & Breast & Colorectal & Ovarian \\
\hline Currently available & 15 & 15 & 7 \\
Under development & 22 & 19 & 14 \\
Primary prevention & 1 & 1 & 0 \\
Detection & 0 & 8 & 7 \\
Prognosis & 2 & 0 & 0 \\
Diagnosis & 12 & 8 & 4 \\
Management & 7 & 2 & 3 \\
\hline Compiled by author based on raw data presented by the AHRQ.25 \\
\hline
\end{tabular}

colon cancer genes. ${ }^{21}$ One case entailed a suit and countersuit between OncorMed and Myriad, which was settled out of court. The other BRCA case was between Myriad and University of Pennsylvania, which was also settled out of court.

\section{Commercialization}

Myriad's centralized testing service does provide some benefits to patients, including Myriad's ability to provide free testing to first-degree relatives to elucidate variants of uncertain clinical significance.

This case study demonstrates several major implications of patents on access. First, the main effect of the patent appears to be on volume rather than price.

1. Any price effect attributable to patents is buried in noise and confounding variables.

2. Myriad's patent position has made it in effect a sole provider of clinical $B R C A$ testing in the United States and indeed $B R C A$ testing in clinical research except when such testing is conducted at the same research institution as the research.

Based on per-amplicon charges, price data - comparing mutation testing for colon and breast cancer at Myriad and comparing $B R C A$ testing to colon cancer predisposition testingsuggest a small price effect, if any, and suggest the main impact of patenting is to drive volume to Myriad for BRCA testing. The price data constitute an imperfect comparison for many reasons. Colon and $B R C A$ cancer testing does not compare patented with unpatented sequences, but rather a group of patents aggregated by Myriad genetics compared with colon cancer gene tests nonexclusively licensed by several academic institutions that are presumably collecting royalties. Moreover, one major constraint on pricing is the reimbursement system, which codes genetic tests and limits price flexibility. The price comparison does, however, at least provide a benchmark and shows any price effects of patents in these two kinds of genetic testing are not of the magnitude associated with therapeutic pharmaceuticals and some other technologies, for which patents command dramatic price premiums for a patented versus generic product.

The downstream costs of a positive test can be far greater than the test itself, including counseling and potential surgical action. ${ }^{65}$ Thus, for any patient contemplating the combined costs of the test and surgery in the event of a positive test, the cost of genetic testing would be a relatively small share of the total.

Second, the coverage and reimbursement practices of insurers and other payers are crucial. Anecdotal reports from interviews with laboratory employees note that many nonprofit centers charge patients up front for genetic testing. These anecdotal reports note that insurance companies are slow to respond to claims for genetic tests and that such tardy reimbursements induced nonprofit centers to either charge differential rates for cash-paying and third-party tests or to drop the thirdparty payer option altogether (so that payment is paid out-ofpocket up front and patients seek reimbursement for themselves from their insurer or health plan). For its part, Myriad provides a wide variety of payment options as noted on its "Reimbursement Assistance Program" Web site, both insurance based and cash based. ${ }^{66}$ Myriad reports that initial inconsistency of coverage and reimbursement is less of an issue now. A much larger number of agreements and more consistent coverage and reimbursement have reduced the number of self-pay patients to single-digit percentages of its clientele. Myriad has established 
contracts or payment agreements with $>300$ carriers and has received reimbursement from $>2500$ health plans (W. Rusconi, personal communication, 2008).

Finally, as the monopoly provider for $B R C A$ testing Myriad will benefit from receiving the entire volume of $B R C A$ tests through its laboratories no matter what it charges, although that volume will certainly vary with the price point. The price comparison we made is compatible with a scenario in which Myriad, as a monopolist, maximizes its profit through price discrimination in which it charges the highest price to those women who most value the test. According to standard economic analysis of monopolist behavior, such discrimination in pricing for different customers would be expected, and paradoxically can enable the monopolist to lower prices for those with lower willingness or ability to pay (in Myriad's case, through its patient access programs). This flexibility is, however, entirely at the discretion of the company. Thus, the patent premium depends on both the price elasticity of demand for $B R C A$ testing and on how Myriad has chosen to set its price point for different purchasers, including consumers with lower ability to pay.

Other firms may enter the breast cancer susceptibility testing market. Myriad is not alone in building a dedicated testing facility around its gene patents. InterGenetics, Inc., is developing OncoVue, the "next-generation" genetic breast cancer risk test that will be available through a network of breast care centers. ${ }^{67}$ How this facility will affect the $B R C A$ market is yet to be seen. OncoVue-BRE ${ }^{\circledR}$ tests genes that, when combined, confer a moderately increased risk. The target population is the general population rather than those with family history. Effectively, this test seeks to determine risk for those not in the $B R C A$ risk category. Hence, the tests are more complementary than competitive. In September 2008, Perlegen announced that it will release a breast cancer diagnostic panel intended to guide treatment choices and provide risk stratification, in which case it would compete with Myriad's testing. ${ }^{68}$ Many of the "personal genomics" firms offering genome-wide scans, such as 23 andMe, Navigenics, SeqWright, Knome, and deCODEme, also include some analysis of cancer risk, including breast and colon cancers. None of these genome-wide cancer risk-assessment tests, however, offers comprehensive analysis of $B R C A$, FAP, or HNPCC genes, and so genome-wide scans are not comparable with those genetic testing services for high-risk families. The exception is the full-sequence Knome service. If a cancer susceptibility mutation were identified in the Knome full genomic sequence, it would require retesting for the identified mutation in a CLIA-certified laboratory to ensure reliability of the result, which the patient could obtain by referral, or which Knome might bundle with its initial price as a subcontracted service. (The price on Knome's Web site was originally $\$ 350,000$ for full-genome, full-sequence analysis. The Web site now asks prospective customers to call for individualized pricing, but Steven Pinker reported it to be $\$ 99,000$ in his January 2009 article in the New York Times magazine. ${ }^{69}$ The idea of subcontracting to CLIA-approved laboratories was discussed by Duke research assistant professor Misha Angrist and Knome CEO and founder Jorge Conde in November 2008.)

\section{What's going on in Australia?}

As this case study was being prepared, a controversy over $B R C A$ testing erupted in Australia. This was precipitated when GTG, Myriad's licensee in Australia and New Zealand, sent cease-and-desist letters to laboratories testing for $B R C A$ in its licensing territory. ${ }^{70-73}$ GTG had announced in 2003 that, when it secured the license, it would allow unlicensed testing as a "gift" to the people of Australia. It changed this policy and decided to enforce its patent rights, and the policy change became public in July 2008 when it was widely covered in the Australian public media. ${ }^{74,75}$ On October 31 , as the November 6 deadline it had set in the cease-and-desist letters loomed, GTG announced it would refrain from enforcing its patent rights pending discussions with "all the relevant stakeholders." 18 It is now the subject of an Australian Senate inquiry. ${ }^{76,77}$ The decisions about enforcement of licensing for BRCA testing may have stemmed from financial pressures on GTG, especially in light of its dwindling stock price, a need to generate revenues, and some disarray in the company's governance. According to pricing data from the NASDAQ stock exchange, GTG's stock price drifted downward during the year from a high of $\$ 5.00$ per share on November 29, 2007, to $\$ 0.66$ on November 4,2008 . In addition to the July 2008 change of policy about $B R C A$ testing, the company also announced its intention to remove five of seven directors at its November 19, 2008, Board meeting, leaving only two directors, which would cause it to fall out of compliance with its corporate bylaws. The proposed new Board member declined to serve, leading to a proposal for an interim board appointment. ${ }^{78}$ Although not directly relevant to US policy, the developments in Australia did spill over to coverage in the United States; GTG actions in Australia also indicate that companies under financial stress may turn to patent assets as revenue sources when their company's survival is being threatened. (See Text box for an update.)

\section{Communication/marketing}

Myriad's position as sole US provider of BRCA testing increases its incentives for communication and marketing up to the point of market saturation. The incentive to advertise the service and broaden the market is stronger for a monopoly provider than in a shared market because a monopolist will gain the full benefit of market expansion. In a competitive market, advertising may increase market share of a given provider or it can expand the size of the market, but the expansion effect spills over to benefit competitors as well, and so the incentive to advertise is weaker. Once a market is saturated, a monopolist no longer gains from advertising to expand market (but may advertise for other reasons).

For the same reason, communication and marketing incentives are also strong to educate health professionals who order the tests, because any increase in orders results in higher volume of testing for Myriad. Again, this increase is not shared with other providers; Myriad gets the full benefit of any market expansion. The downside of this incentive is that Myriad's financial incentive is to expand testing, not just appropriate testing. Myriad makes money off of any test, regardless of whether the person is actually at risk. The incentive is not just for appropriate testing; the risk is overutilization.

There are some checks on overutilization. Medical societies establish guidelines for their membership which, in turn, form the basis for payer coverage criteria. Insurers and other payers work not to reimburse for tests when patients do not meet clinical appropriateness criteria. One further check is the bottleneck of determining eligibility for testing. The limited pretest counseling resource is used to fulfill specific payer criteria for high-risk patients eligible for coverage and reimbursement. Low-risk candidates can clog the pretest filters of counseling and coverage determination, occupying them with cases that would not ultimately lead to testing or, if tested, would not be reimbursed by third parties.

In the context of breast cancer testing, Myriad has a strong incentive to "get the word out" about genetic testing for inher- 
ited risk of breast cancer. This incentive is stronger for $B R C A$ testing, for which Myriad is sole US provider, than for colon cancer testing, where there are alternative providers. This may be one reason for Myriad's past direct-to-consumer advertising - both the 2002 pilot in Denver and Atlanta and the 20072008 campaign in the northeastern states-focused on breast and ovarian cancer testing rather than Myriad's colon cancer testing services. The social benefit from this incentive is more public knowledge of test availability. The potential harms are overutilization of $B R C A$ genetic testing, and public fear of genetic risk of breast cancer amplified by advertising.

Caulfield and Gold note in their 2000 article from Clinical Genetics that:

\begin{abstract}
Myriad Genetics, a commercial testing company that holds patent rights underlying the [BRCA1 and BRCA2] test, does not exclude women without any family history of breast or ovarian cancer from taking its test. This contrasts sharply with the Working Group with Stanford's Program in Genomics, Ethics and Society, which recommends that "for most people, testing for $B R C A 1$ and $B R C A 2$ mutations is not appropriate." Although all genetic testing policies are undoubtedly motivated by a degree of self-interest, it is hard to deny the strong, and possibly adverse, impact of the profit motive in this context. ${ }^{79}$
\end{abstract}

Myriad states it does not want to expand inappropriate testing but rather to saturate testing among high-risk families. Myriad's "television, radio, and print advertising campaign" in September 2002, included the television show ER, Oprah and Better Homes and Gardens. ${ }^{19}$ A follow-up survey on 300 women who had seen the advertisements noted that " $85 \%$ would contact their physician regarding $B R C A$ testing and $62 \%$ would go so far as to switch health care professionals in order to find one who would help them gain access to the test."19 This interest can include spurious demand for the tests and consumes the time of health professionals in filtering out such spurious demand and explaining the complicated genetics of cancer susceptibility to many not actually at elevated risk.

A Centers for Disease Control and Prevention (CDC) survey done during the 2003 direct-to-consumer pilots in Denver and Atlanta compared experience in those direct to consumer (DTC) campaign cities to Raleigh-Durham and Seattle, which did not experience regionally targeted advertising. CDC found an increase in test requests and questions about testing among women, an increase in test ordering among physicians and providers, and no difference in levels of reported anxiety. ${ }^{80}$ The CDC concluded that:

\section{Advertisements might have motivated women interested in learning more about $B R C A 1 / 2$ testing to talk to their physicians and request testing. Findings from the con- sumer survey suggest that women in the pilot cities were more aware of BRCA1/2 testing than those in the com- parison cities. No evidence suggested an increased inter- est in the test among women most suited for BRCA1/2 testing (i.e., those having a first-degree relative). ${ }^{80}$}

Judy Mouchawar and coworkers did the most systematic studies of consumer, provider, and health plan responses to the Denver DTC advertising campaign. They surveyed health professionals and consumers and assessed impact on health systems in the advertising market (Denver Kaiser Permanente) and in a compar- ison city (Detroit) and health system (Henry Ford) not exposed to the advertisements. The number of women at high risk who got referred went up by 2.38 times, from 100 to 238, suggesting that $>100$ women at high risk got tested who otherwise might not have known about the test. The number of women contacting the systems about testing rose 3.46 times (from 144 to 499 ) with advertising, including a higher fraction of women not at high risk and, therefore, not warranting testing (the fraction at high risk dropped from $69 \%$ to $48 \%$ ). ${ }^{81}$ Thus, the number of women at risk who might benefit from testing went up, but there was also a dilution of such high-risk women among an even greater increase of contacts about testing. There was no increase in actual testing among women with low risk in the population studied. This caveat is important, because Kaiser Permanente has practice guidelines for $B R C A$ testing, and it cooperated with Myriad to prepare for a surge in demand during the DTC advertising period. Physician surveys showed a modest effect on physicians, with $3 \%$ reporting significant patient anxiety, $19 \%$ reporting significant increase in time spent explaining and another $23 \%$ a little extra time, and $7 \%$ reporting significant and $8 \%$ a little strain on the doctor-patient relationship. ${ }^{82}$ Eighty-two percent reported the DTC campaign had no effect on their relationship with patients.

Consumers reporting "any anxiety" varied from 28\% (low family risk) to $55 \%$ (high risk). Anxiety was most pronounced among Latina/Hispanic women (65\%), and much more common in low-income (62\% among those making less than $\$ 30,000)$ than high-income women $(30 \%$ among those making over $\$ 80,000) .82$ Among those exposed to the advertisement, $63 \%$ reported no anxiety at all, but $65 \%$ reported feeling somewhat or very concerned. It is hard to fully interpret the answers to various questions. Physicians were asked to assess the effect overall on their practice, and $6 \%$ were positive or very positive, $14 \%$ were negative or very negative, and $79 \%$ reported no effect. $^{82}$

The overall impact of the DTC advertisement campaign on the Kaiser Permanente health system in Denver was a more than two-fold increase in the number of women in the high-risk category getting tested, a more than three-fold surge in contacts about testing, a moderate increase in anxiety among consumers, and a mixed reaction among physicians, but with the vast majority reporting no effect. A comparison between the experience of physicians and women in Kaiser Permanente to other parts of the health system in Denver at the same time would have been immensely useful, as the Kaiser Permanente system is much more organized for genetic services than general medical care. The Mouchawar studies are illuminating as a "best case" of a health system prepared for a surge and with practice guidelines in place; it is very unlikely to represent the effects of the advertisement campaign elsewhere in Denver (or anywhere else) with a less organized and prepared genetic services program and with physicians less educated about how to triage testing.

Myriad Genetics' marketing campaign both to providers and patients is concisely summarized in Dr. Parthasarathy's book. ${ }^{19}$ Myriad aggressively marketed its $B R C A$ genetic tests to providers through a "Professional Education Program," through continuing education accredited by the American Medical Association, and at various professional meetings. Highlighting the importance of reaching providers with such educational campaigns, one study showed that high-risk women - those eligible for $B R C A$ testing based on family history-were three times as likely to get tested after a physician recommendation as those who did not get such a recommendation. ${ }^{83}$

On September 10, 2007, Myriad announced it would begin a new "public awareness campaign" throughout the northeastern United States to spread the word about BRCA testing. ${ }^{84}$ This 
campaign concluded in March 2008. Myriad's quarterly report through March 2008 reported a jump in molecular diagnostic revenue from $\$ 38$ to $\$ 59$ million and attributed the 55\% jump to its northeast advertising campaign. ${ }^{85}$ Given these financial results, it is not surprising Myriad is said to be contemplating similar DTC advertising initiatives in Texas and Florida or elsewhere. (Suggestions of future DTC advertising plans were reported to the authors but were neither confirmed nor denied by Myriad staff.) This clearly illustrates the link between status as a single provider and incentives for direct-to-consumer advertising, with single provider status in this case associated with exclusive patent rights for $B R C A$ testing.

We have not found similar marketing campaigns launched by Myriad or other groups on behalf of other tests. However, a future research project could compare $B R C A$ testing uptake in the Denver and Atlanta markets in 2002 or in the northeast in 2007-2008, where Myriad's advertising was concentrated, to utilization in other regions. This could be done through a large health-insurer's database or using billing records of Medicare/ Medicaid for relevant CPT codes matched to clinical indications. The link between DTC advertising and patenting is mediated by the monopoly incentive for advertising noted above. Dynamics in genetic testing markets have changed considerably since 2002. The growing number of physicians ordering genetic tests, the greater availability of third-party coverage, the accumulating experience in using genetic tests to manage hereditary cancer risk, and the greater consumer awareness about genetic testing all suggest the 2003 surveys may not predict current or future behavior. Moreover, the increasing conspicuousness and commercial interest in personal genomics may also change perceptions and behaviors. DTC advertising is not directly related to access per se although it is highly relevant to projections of demand and perceptions of access.

\section{Adoption by third-party payers}

Myriad has a strong incentive to develop the infrastructure to handle billing and payment for $B R C A$ testing because it captures all the revenues from market expansion. This benefits the company, but it also benefits patients to the degree it relieves them of the hassle and paperwork of dealing with health plans and insurers, and it benefits providers by relieving them of those duties as well as legal liability for test inaccuracies. The countervailing force here is that Myriad as a sole-source provider requires providers to send samples, track paperwork, and bill for services providers might otherwise handle at their own institution through internal billing and administrative procedures. The comparison with colon cancer testing is suggestive here. Most colon cancer genetic testing is done by the handful of laboratories set up to offer this complex set of tests, and the test algorithms for $B R C A$ and colon cancer susceptibility genes seem to have comparable costs and decision pathways. It, thus, seems there is some advantage to consolidating testing at a few laboratories that can attain sufficient volume to justify sunk costs in developing the test and resources to ensure quality and reduce legal liability for errors. In the case of colon cancer testing, this has resulted in an oligopoly; $B R C A$ patents have made testing a Myriad monopoly in the United States.

The US monopoly on BRCA testing may not be absolute; there is no legal barrier to sending samples abroad, and US courts would be unlikely to interpret merely sending results from tests performed abroad (information) back to the United States as infringement. Myriad would have grounds for infringement liability only if the invention (making and using the patented sequences and methods) were performed abroad in a jurisdiction where those activities are claimed in patents, and Myriad would have to sue in those juris- dictions. Laboratories in countries with diagnostic use exemptions would not face infringement liability.

Regarding third-party payers, at least one study noted in the Lewin Group report showed that as of late 1995, "only $4 \%$ of insurance providers... had granted coverage of $B R C A$ testing[, and] $55 \%$ of respondents cited concerns about the high cost of $B R C A$ testing, averaging $\$ 2400$ per patient." 5 As noted above, these data no longer represent practices for $B R C A$ testing, which Myriad reports now generally is covered for roughly $95 \%$ of those requesting tests and reimbursed to cover $90 \%$ of their charges. The same study cited by the Lewin Group had two other findings of relevance to patented gene tests. First, only $6 \%$ of the decision makers for private health insurance plans would cover $B R C A$ testing if it were extended to all women in the general population, whereas $48 \%$ would offer it if it were restricted only to women with a positive family history who were enrolled in an approved research trial. Second, the proclivity to offer coverage was sharply dependent on cost: $25 \%$ were willing to cover it if the testing cost were $\$ 250$, but only $14 \%$ would cover if the cost rose to $\$ 1000$ (it was $\$ 2400$ at the time). Taken at face value, the figures imply that even if gene patents confer a premium of $\$ 750$, this would only reduce the likelihood of third-party coverage by $11 \%$. However, the low response rate $(22 \%)$ and early timing of this study limit the current usefulness of this study. ${ }^{22}$

In 1998, Myriad reported that $>300$ different insurers covered $B R C A 1$ and $B R C A 2$ testing; they further stated that $94.3 \%$ of processed claims for $B R C A 1$ and $B R C A 2$ testing had resulted in at least partial payment from insurance companies (suggesting the test was covered to some extent). ${ }^{86}$ As of $2002,38 \%$ of testers said they had no problems in getting coverage for genetic services from their insurance plan. However, a more telling statistic was that only $59 \%$ of women undergoing full-sequence $B R C A$ analysis in one study (in which $99 \%$ of women had health insurance) filed health insurance claims. ${ }^{23}$ Furthermore, $15 \%$ of women in a second study undergoing BRCA analysis chose to self-pay, and each of those women did so in fear of insurance or employment discrimination. ${ }^{24}$ As noted above, Myriad states that only $\sim 5 \%$ of patients now self-pay and more than 2500 payers and health plans have reimbursed testing with Myriad. Finally, the enactment of the Genetic Information Nondiscrimination Act of 2008, and its implementation in 2009 and 2010, may reduce fears of discrimination in employment and health insurance.

In the most recent study to address reimbursement for genetic testing, $56 \%$ of nontesters from a sample who had received genetic counseling services and declined testing said they could not afford all costs of the test or their share not covered by insurance, yet, more than half also reported income of over $\$ 70,000$ annually. ${ }^{87}$ Of only 77 individuals for whom insurance status was reported, $42 \%$ had insurance that provided no coverage for testing, 25\% had partial coverage, and the remainder had full coverage. However, this was not a random sample of the population, because no one was reported as uninsured. Nationally, $18.8 \%$ of women aged 19-64 years are uninsured, ${ }^{88}$ so, if we assume the same is true of women with $B R C A$ mutations and that $42 \%$ of the remainder are insured but have no coverage for $B R C A$ testing, this would imply that roughly half of the at-risk group had no insurance coverage for this test at that time.

One conclusion from multiple studies is that when payment is out-of-pocket, price has a strong and direct impact on testing utilization and, thus, affects patient access. People do forego potentially beneficial genetic tests when they are expensive and not covered by health plans or insurance. Access is, thus, linked tightly to coverage and reimbursement policies, which are far more important than any direct patent 
effects. Patent status matters to the degree it affects price, where high prices require payers to assess a specific new test. Patent status may also affect likelihood to create a bargaining impasse with payers, if patent holders and payers simply cannot agree on reimbursement. The $B R C A$ experience suggests that $>10$ years, the majority of payers have decided to cover most of the cost of a test when its use is restricted to those at high risk. For those who are not covered by such payers, access is still a problem, in part, because of price.

Problems in access may still occur with: (1) Medicaid programs, (2) insurance policies that exclude all genetic testing, and (3) practices and health plans (e.g., in Southern California), where there is a strong financial incentive to minimize utilization. These access constraints, however, do not seem to be keyed to patent status, but rather blanket policies focused on cost containment and contractual transaction costs.

\section{Coverage for risk-reducing surgery}

A national study on coverage for prospective mastectomy or oophorectomy showed that $10-11 \%$ of private insurers and $48-50 \%$ of public health plans had policies that specifically denied coverage for risk-reducing surgery for women with $B R C A$ mutations; $52-64 \%$ of private insurers and $40 \%$ of public carriers had no identifiable policy regarding coverage of either form of surgery for such women. ${ }^{89}$

A retrospective analysis of 219 Memorial Sloan-Kettering Cancer Center patients with known BRCA1/2 mutations found that of 35 women undergoing 39 risk-reducing mastectomies or oophorectomies, 97\% were covered in full (minus applicable deductibles and coinsurance). The single instance in which an indemnity plan refused to provide coverage occurred in 1997, when there were few data about the efficacy of prophylactic oophorectomy. ${ }^{90}$ This study is now 8 years old, however, and clinicians with whom we have spoken believe that prophylactic surgery in mutation-positive women is broadly covered, although we have no empirical data to corroborate that impression.

Adoption by third-party payers and by providers and testing laboratories is only a rough proxy for patient access. If possible, future research should focus on getting at direct patient access data or at least at utilization rather than highly indirect measures such as number of providers or price.

\section{Consumer utilization}

In studies done several years ago, $19-74 \%$ of at-risk individuals who could benefit from $B R C A$ testing were not being tested. ${ }^{87}$ Cost was not the only consideration: nearly $70 \%$ of patients eligible for free $B R C A$ testing elected to get tested; however, cost certainly mattered because only $22 \%$ of self-pay patients in the same sample chose to be tested. ${ }^{87}$ The financial barriers to individual patients appear to have been reduced considerably for those who have health plans; so, the financial access questions reduce to how many have such coverage, which as shown above, is still a gray area in terms of hard numbers. In the RAND Health Insurance Experiment, the price elasticity of demand for outpatient health services for those with high cost sharing was $-0.31 .{ }^{91}$ If the patent premium on $B R C A$ were $50 \%$, for example, this would predict $15.5 \%$ fewer high-risk patients without coverage would purchase the test. Any reduction in access because of cost, however, is difficult to attribute to $B R C A$ patents because of the absence of a clear price effect of the patents. Our data do not allow us to tease out any price-utilization effects attributable to patents per se.

Finally, Table 1 notes the difference in number of providers for the three genetic tests, with Myriad as the sole $B R C A$ full-sequence provider, nine providers for the Lynch syndrome tests, and five for the FAP test. This sole-provider status of Myriad for $B R C A$ testing in the United States is clearly attributable to patent status, although differences in patent status and patent enforcement outside the United States have resulted in Myriad not being sole provider in other jurisdictions.

\section{UPDATE ON BRCA AND COLORECTAL CANCER TESTING, PATENTS, AND LICENSING (FEBRUARY 2010)}

Several events have taken place since the case studies were submitted to Secretary's Advisory Committee on Genetics, Health, and Society (SACGHS) in February 2009 to be posted with the "public comment draft" of the SACGHS report in March 2009. Some of the most salient events are described below.

\section{Events in the United States}

On May 12, 2009, a group of plaintiffs - professional medical organizations, genetic researchers, clinical geneticists, genetic counselors, breast cancer advocacy groups, and breast cancer patients - sued Myriad Genetics, the Directors of the University of Utah Research Foundation, and the US Patent and Trademark Office in the Southern New York Federal District Court. ${ }^{104}$ In the plaintiffs' eyes, claims in patents assigned to Myriad Genetics and the University of Utah cover "products of nature, laws of nature and/or natural phenomena, and abstract ideas or basic human knowledge or thought."104 The plaintiffs assert that the patent claims violate Article I, section 8, clause 8 of the Constitution, which does not allow exclusive rights to scientific laws or products of nature, and the First Amendment, which does not allow preventing patients from accessing their genetic information. They also assert the claims are not within the realm of patentable subject material enumerated in 35 US Code Section 101. The plaintiffs have asked the Court to find the disputed patent claims "invalid and/or unenforceable" and to prevent the defendants from enforcing their patent claims. ${ }^{104}$

As of February, 2010, the parties are involved in initial procedural matters. The defendants argue that the plaintiffs lack a constitutional or statutory basis to challenge the patents, that Myriad has not enforced its patents against the defendants recently enough to create a case or indicated an intent to do so, and that the Directors have no business in New York relevant to the case that would put it within the Southern District Court of New York's jurisdiction. ${ }^{105,106}$ On the other side, the plaintiffs made a motion for jurisdictional discovery to allow them to gather evidence to prove that they have a controversy suitable for judicial resolution and that the court currently hearing the case has the legal authority to do so. ${ }^{107}$ The plaintiffs also filed a motion for summary judgment, which asked the court to rule on the legal questions based on the facts already provided to the court. ${ }^{108}$ Several professional organizations and advocacy groups ranging from the American Medical Association to the Pro-Choice Alliance for Responsible Research to the Indigenous Peoples Council on Biocolonialism have filed amicus briefs in favor of the plaintiffs' motions for summary judgment. Briefs in favor of the plaintiffs are available under "Case Documents" at http://www. aclu.org/freespeech/gen/brca.html. Presiding Judge Robert W. 
Sweet heard the plaintiffs' motions for summary judgment and jurisdictional discovery on September 30, 2009. Judge Sweet denied the defendants' motion to dismiss on November 1.109

His ruling indicates that he understands the case's importance for medical research and innovation. "The challenges to the patents-in-suit raise questions of difficult legal dimensions concerning constitutional protections over the information that serves as our genetic identities and the need to adopt policies that promote scientific innovation in biomedical research. The widespread use of gene sequence information as the foundation for biomedical research means that resolution of these issues will have far-reaching implications, not only for genebased health care and the health of millions of women facing the specter of breast cancer, but also for the future course of biomedical research."109

Oral hearings took place on February 2, 2010 in federal district court. On March 29, 2010, Judge Sweet ruled that the contested patent claims are invalid under 35 US Code Section 101, ruling that DNA is not patentable subject matter, and dismissed the plaintiffs' Constitutional claims. Appeals are expected. Court documents are available at http://dockets.justia.com/docket/court-nysdce/case_no-1:2009 cv04515/case_id-345544/.

\section{Events in Europe}

Myriad's legal position in Europe has changed as the result of an opposition procedure launched in 2001 and concluded in November 2008. The partial restoration of claims in patents covering the BRCA1 gene in Europe was announced but not publicly available at the time the case studies were submitted to SACGHS. The claims and the record of the opposition proceedings have since been made public. The European opposition procedure is a way for third parties to challenge patents through administrative proceedings, short of litigation. The Institut Curie began in opposition procedure in 2001, when it feared that Myriad would prevent the institution from using its inhouse test. ${ }^{34}$ The Institut challenged the validity of Myriad's key patent for BRCAl testing. Later, the administrative center for Parisian hospitals, another French laboratory, other European research institutions and medical associations, and Greenpeace joined the opposition proceeding. ${ }^{110}$ In November 2008, the European Patent Office stated that it would allow a set of patent claims it had revoked pending the opposition proceeding. Myriad retained claims to "determining whether there is germline alteration $185 \mathrm{delAG}-$ $>$ ter39 in the BRCA1 gene in a tissue sample of said subject" and then determining a patient's predisposition to breast or ovarian cancer. Myriad also retained claims associated to diagnostic methods and biological materials. ${ }^{11}$ The $185 \mathrm{del} A \mathrm{G}$ mutation, one of the first discovered and most common among Hispanic and Ashkenazim Jewish populations, is claimed. ${ }^{112,113}$

Regardless of its patent claims, Myriad must contend with diagnostic use exemptions and compulsory licensing provisions in several national jurisdictions, including France and Belgium, ${ }^{114,115}$ in effect meaning these claims cannot be asserted against such uses. Authorities in those countries could be petitioned to exercise statutory authority to compel licensing of patents being used in a way that adversely affects public health. Diagnostic use of gene patents was explicitly discussed as such a possible use of these statutory licensing authorities when the laws were being passed. ${ }^{144,115}$ The situation in Europe, thus, remains uncertain, with Myriad now having stronger patent rights, but also facing untested and hitherto unused exemptions and compulsory licensing provisions in some of the largest markets based on laws passed with $B R C A$ testing specifically in mind. A draft European Council regulation on a European Union-wide patent system discussed in early October at the Working Party on Intellectual Property, an organ of the Council of the European Union, includedclauses for compulsory licensing. ${ }^{116}$ Those clauses may add to Myriad's legal and political difficulties in competing in Europe. The public attitudes in Europe may also mirror those in Australia that led Myriad's Australian licensee to back away from enforcement actions (see below). Efforts to enforce patent rights in Europe might provoke similarly intense public controversy.

\section{Events in Australia}

In Australia, the 2008 controversy over a decision by GTG (Australian Stock Exchange) to reassert its intellectual property rights of BRCA1 and 2 testing was resolved for all practical purposes in December 2008, although a Senate investigation continues. GTG has, thus, backed away from reasserting its threats to enforce patent rights licensed from Myriad genetics. According to a public announcement from GTG, "On November 24th, 2008, Genetic Technologies Limited...informed the Market that its new Board of Directors, which largely replaced the previous Board, was undertaking a formal review of the Company's recent decision to enforce its $B R C A$ testing rights. GTG is now pleased to announce that the new Board has duly completed this review and resolved to immediately revert to its original decision to allow other laboratories in Australia to freely perform BRCA testing."117 The company's stock on the Australian Stock Exchange was worth less than 10 cents a share as of October 20, 2009. ${ }^{118}$

GTG's decision to back down may have been influenced by two national investigations. The Australian Competition and Consumer Commission launched one investigation in October 2008. ${ }^{75}$ The Australian Senate also launched an investigation and held a series of hearings. The Australian Senate asked the Committee on Community Affairs for a report on " $[\mathrm{t}]$ he impact of the granting of patents in Australia over human and microbial genes and noncoding sequences, proteins, and their derivatives, including those materials in an isolated form."119 The Committee's mandate included a request for inquiry into statutory changes and gene patents' impact on medical services, education, research, and "the health and wellbeing of the Australian people."119

The Senate Committee held hearings in March, August, and September, 2009, when doctors, industry representatives, representatives of the Australian government agency that grants patents, intellectual property experts, and patient advocacy groups gave testimony. ${ }^{120}$ Rhetoric was, at times, fiery. Senator Heffernan asked one speaker, for example, whether, "given the overwhelming evidence from the clinically driven, vocationally guided and humanely inspired side of this debate, which is lining up against, from what I can see, a bunch of lawyers, bankers, and people who are financially driven, is it time for the [Australian] Commonwealth to step up to the plate and fund a test case and we can just sort this out in the courts?."121 Not all Senators were as forceful in their comments, but discussion was spirited and referred back to Myriad Genetics. The committee was scheduled to report to the Senate on November 26, 2009, but its report has been delayed until at least March, 2010. ${ }^{122}$ 


\section{ACKNOWLEDGMENTS}

The case study authors have no consultancies, stock ownership, grants, or equity interests that would create financial conflicts of interest. The Center for Genome Ethics, Law \& Policy accepts no industry funding. Dr. Robert Cook-Deegan is listed on the British Medical Journal roster of physicians who have pledged to remain independent of industry funding (http:// www.tseed.com/pdfs/bmj.pdf); more details about how the case studies were done are noted in a July 29, 2009, letter to the Secretary's Advisory Committee on Genetics, Health, \& Society (http://www.genome.duke.edu/centers/gelp/documents/ SACGHSResponsetopubliccomments.pdf).

All interviews were conducted under Duke University IRBapproved protocol 1277 and usually conducted by phone and recorded. Researchers obtained informed consent from subjects. These interviews are covered by a federal certificate of confidentiality.

This case study was carried out under grant P50 003391, co-funded by the National Human Genome Research Institute and US Department of Energy and supplemented by funding from The Duke Endowment.

We wish to thank David Ridley, Tracy Lewis, and Wesley Cohen of the Fuqua School of Business for their helpful comments. The case study was also reviewed by William Rusconi, Faye Eggerding, and Michael Hopkins for the Secretary's Advisory Committee on Genetics, Health, and Society.

\section{REFERENCES}

1. Rusconi W. Patenting and licensing of the breast cancer susceptibility genes - BRCA1 and BRCA2. Washington, DC: National Academies, 2005. Available at: http://www.genome.duke.edu/centers/cpg/documents/ project 1/clinical-genetic-testing/NAS\%20Patents\%20and\%20BRCA\%202-112005\%20\%282\%29.pdf. Accessed November 18, 2009.

2. National Human Genome Research Institute. Breast cancer information core. Available at: http://research.nhgri.nih.gov/bic/. Accessed September 25, 2008.

3. Parthasarathy S. Architectures of genetic medicine: comparing genetic testing for breast cancer in the USA and UK. Soc Stud Med 2005:35:5-40.

4. Myriad Genetics, U.S. National Cancer Institute. Memorandum of understanding. Salt Lake, Utah: Myriad Genetics, 1999.

5. Lewin Group. The value of diagnostics: innovation, adoption, and diffusion into health care 2005. Falls Church, VA: Lewin Group, 2005.

6. Sevilla C, Julian-Reynier C, Eisinger F, et al. Impact of gene patents on the cost-effective delivery of health care: the case of $B R C A 1$ genetic testing. Int J Technol Assess Health Care 2003;19:287-300.

7. Evaluation of Genomic Applications in Practice and Prevention (EGAPP) Working Group. Recommendations from the EGAPP Working Group: genetic testing strategies in newly diagnosed individuals with colorectal cancer aimed at reducing morbidity and mortality from Lynch syndrome relatives. Genet Med 2009;11:35-41.

8. Palomaki GE, McClain MR, Melillo S, Hampel HL, Thibodeau SN. EGAPP supplementary evidence review: DNA testing strategies aimed at reducing morbidity and mortality from Lynch syndrome. Genet Med 2009; 11:42-65.

9. Walsh T, Casadei $\mathrm{S}$, Coats $\mathrm{KH}$, et al. Spectrum of mutations in BRCAl, BRCA2, CHEK2, and TP53 in families at high risk of breast cancer. JAMA 2006;295:1379-1388.

10. Statement of Marc Grodman at stifling or stimulating - the role of gene patents in research and genetic testing. Washington, DC: House Judiciary Subcommittee on Courts, the Internet and Intellectual Property, 2007. Available at: http://judiciary.house.gov/hearings/pdf/Grodman071030.pdf. Accessed March 2, 2010

11. Written statement of Wendy Chung at stifling or stimulating - the role of gene patents in research and genetic testing. Washington, DC: House Judiciary Subcommittee on Courts, the Internet and Intellectual Property, 2007. Available at: http://judiciary.house.gov/hearings/pdf/Grodman071030.pdf. Accessed March 2, 2010.

12. Judkins T, Hendrickson BC, Gonzales D, et al. Detection of large rearrangement mutations in $B R C A 1$ and $B R C A 2$ in 528 high risk families from North America by quantitative PCR based gene dose analysis. Paper presented at American Society of Human Genetics 54th Annual Meeting. Toronto, Canada, 2004. Available at: http://www.ashg.org/genetics/ abstracts/abs04/f518.htm. Accessed July 11, 2008.
13. Hartmann C, John A, Klaes R, et al. Large BRCAl gene deletions are found in 3\% of German high-risk breast cancer families. Hum Mutat 2004;24:534.

14. Hendrickson B, Judkins T, Deffenbaugh A, Pyne K, Ward B, Scholl T. Recurrent intragenic rearrangement mutations in the tumor suppressor gene $B R C A 1$ : Prevalence results from 12,272 patients at high risk for breast and/or ovarian cancers and methods of biochemical analysis. Paper presented at 40th Annual Meeting of the American Society of Clinical Oncology. New Orleans, LA, 2004

15. Spence W, Judkins T, Schoenberger J, et al. Clinical testing experience for large genomic rearrangements in the BRCA1 and BRCA2 genes for hereditary breast and ovarian cancer. Paper presented at American Society for Human Genetics Meeting. San Diego, CA, October 23-27, 2007.

16. Harmon A. The DNA age: couples cull embryos to halt heritage of cancer. New York Times. September 3, 2006:A1.

17. van Orsouw N, Dhanda R, Elhaji Y, et al. A highly accurate, low cost test for BRCA1 mutations. J Med Genet 1999;36:747-753.

18. Genetic Technologies Limited. Further clarifications on BRCA testing. Public announcement for "personal use only." Available at: http://www.gtg. com.au/index.asp? menuid $=060.070 .130 \&$ artid $=10740 \&$ function $=$ NewsArticle.Accessed November 8, 2008.

19. Parthasarathy S. Building genetic medicine: breast cancer, technology, and the comparative politics of health care. Cambridge: MIT Press, 2007.

20. Cho M, Illangasekare S, Weaver M, Leonard D, Merz J. Effects of patents and licenses on provision of clinical genetic testing services. J Mol Diagn 2003;5:3-8.

21. Holman CM. The impact of human gene patents on innovation and access: a survey of human gene patent litigation. UMKC Law Review 2007;76: 295-361.

22. Schoonmaker M, Bernhardt B, Holtzman N. Factors influencing health insurers' decisions to cover new genetic technologies. Int $J$ Technol Assess Health Care 2000;16:178-189.

23. Lee S, Bernhardt B, Helzlsouer K. Utilization of BRCA1/2 genetic testing in the clinical setting: report from a single institution. Cancer 2002;94: $1876-1885$

24. Peterson E, Milliron K, Lewis K, Goold S, Merajver S. Health insurance and discrimination concerns and BRCA1/2 testing in a clinic population. Cancer Epidemiol Biomarkers Prev 2002;11:79-87.

25. Agency for Healthcare Research. Genetic tests for cancer: technology assessment. Rockville, MD: Agency for Healthcare Research and Quality, January 9, 2006. Available at: http://www.ahrq.gov/clinic/ta/gentests/ gentests.pdf. Accessed May 5, 2007.

26. American Cancer Society. Cancer facts and figures 2007. Available at: http://www.cancer.org/downloads/STT/CAFF2007PWsecured.pdf. Accessed March 10, 2010

27. American Cancer Society. Breast cancer facts and figures, 2005-2006. Available at: http://www.cancer.org/downloads/STT/CAFF2005BrF.pdf. Accessed March 10, 2010.

28. Agency for Healthcare Research and Quality. Genetic risk assessment and BRCA mutation testing for breast and ovarian cancer susceptibility: evidence synthesis 37. Rockville, MD: Agency for Healthcare Research and Quality, 2005.

29. Kaz A, Brentnall T. Genetic testing for colon cancer. Nat Clin Pract Gastroenterol Hepatol 2006;3:670-679.

30. McKusick VA. Entry 120435. Online Mendelia inheritance in man. Available at: http://www.ncbi.nlm.nih.gov/entrez/dispomim.cgi?id=120435. Accessed January 19, 2009.

31. OncorMed. SEC EDGAR filing information: form 10-Q - quarterly report, June 30, 1998. Gaithersburg, MD: OncorMed, 1998. Available at: http:// www.sec.gov/Archives/edgar/data/922821/0000950133-98-003049.txt. Accessed March 9, 2010.

32. OncorMed. SEC EDGAR filing information: form 8-K-current report, July 07, 1998. Gaithersburg, MD: OncorMed, 1998. Available at: http:// www.sec.gov/Archives/edgar/data/922821/0000950133-98-002539.txt. Accessed March 9, 2010.

33. OncorMed. SEC EDGAR Filing Information: form 15-12B - securities registration termination September 30, 1998. Gaithersburg, MD: OncorMed, 1998. Available at: http://www.sec.gov/Archives/edgar/data/ 922821/0000936392-98-001309.txt. Accessed March 9, 2010.

34. Gold ER, Carbone J. Myriad Genetics: in the eye of the policy storm. Genet Med 2010;12(suppl):S39-S70.

35. Sevilla C, Moatti J, Julian-Reynier C, et al. Testing for BRCA1 mutations: a cost-effectiveness analysis. Eur J Hum Genet 2002;10:599-606.

36. Baylor College of Medicine Medical Genetics Laboratories. Prices and CPT codes. Available at: http://www.bcm.edu/geneticlabs/cptcodes.html. Accessed June 6, 2008

37. Harvard Medical School. MLH1, MSH2, and MSH6 sequencing and deletion/duplication analysis for hereditary non-polyposis colorectal cancer (HNPCC) and HNPCC-like syndromes. Available at: http://www.hpcgg. org/LMM/comment/HNPCC_info.jsp. Accessed June 20, 2008.

38. Harvard Medical School. $A P C$ gene sequencing and deletion/duplication analysis for familial adenomatous polyposis (FAP) and FAP-like syndromes. 
Available at: http://www.hpcgg.org/LMM/comment/APC_info.jsp. Accessed July $14,2008$.

39. United States Preventative Services Task Force. Genetic risk assessment and BRCA mutation testing for breast and ovarian cancer susceptibility. Ann Intern Med 2005; 143:355-361.

40. Bonis P, Trikalinos T, Chung M, et al. Hereditary nonpolyposis colorectal cancer: diagnostic strategies and their implications. Evidence report/technology assessment No. 150 prepared by Tufts-New England Medical Center Evidence-based Practice Center under Contract No. 290-02-0022. Rockville, MD: Agency for Healthcare Research, May 2007. Available at: http://www.ahrq.gov/downloads/pub/evidence/pdf/hnpcc/hnpcc.pdf. Accessed June 4, 2008.

41. Levin B, Lieberman D, McFarland B, et al. Screening and surveillance for the early detection of colorectal cancer and adenomatous polyps, 2008: a joint guideline from the American Cancer Society, the US Multi-Society Task Force on Colorectal Cancer, and the American College of Radiology. CA Cancer J Clin 2008;58:130-160

42. National Comprehensive Cancer Network. NCCN Clinical Practice Guidelines in Oncology Colorectal Cancer Screening. V.1.2007.

43. Agency for Healthcare Research. U.S. Preventive Services Task Force: screening for breast cancer summary of recommendations 2002. Rockville, MD: Agency for Healthcare Research, 2002. Available at: http://www. ahrq.gov/clinic/pocketgd09/gcp09s2.htm\#BreastScreening. Accessed March 2, 2010.

44. Saslow D, Boetes C, Burke W, et al. American Cancer Society guidelines for breast screening with MRI as an adjunct to mammography. CA Cancer $J$ Clin 2007;57:75-89.

45. Agency for Healthcare Research. U.S. Preventive Services Task Force: screening for colorectal cancer summary of recommendations 2002. Rockville, MD: Agency for Healthcare Research, 2002.

46. Goldman NA, Restivo A, Goldberg GL. Screening and primary and secondary interventions for patients at high risk for ovarian cancer. Wom Oncol Rev 2003;3:269-274

47. Higashi M, Veenstra D. Managed care in the genomics era: assessing the cost effectiveness of genetic tests. Am J Manag Care 2003;9:493-500.

48. Carroll A, Downs S. Comprehensive cost-utility analysis of newborn screening strategies. Pediatrics 2006;117(5 Pt 2):S287-S295.

49. Cutler DM, Landrum MB, Stewart KA. Intensive medical care and cardiovascular disease disability reductions. Cambridge, MA: National Bureau of Economic Research, May 2006.

50. Murphy KM, Topel RH. The economic value of medical research. Measuring the gains from medical research: an economic approach. Chicago: University of Chicago Press, 2003:41-73.

51. Saam J, Burbidge L, Bowles K, et al. Decline in rate of BRCA1/2 variants of uncertain significance: 2002-2008. Paper presented at National Society of Genetic Counselors Annual Meeting. Los Angeles, CA, 2008.

52. Agency for Healthcare Research. U.S. Preventive Services Task Force: chemoprevention: breast cancer. Rockville, MD: Agency for Healthcare Research, July 2002. Available at: http://www.ahrq.gov/clinic/uspstf/ uspsbrpv.htm. Accessed March 9, 2010.

53. Anderson K, Jacobson J, Heitjan D, et al. Cost-effectiveness of preventive strategies for women with a BRCA1 or a BRCA2 mutation. Ann Intern Med 2006;144:297-407.

54. American Gastroenterological Association. AGA technical review on hereditary colorectal cancer and genetic testing. Gastroenterology 2001;121: $198-213$.

55. Vasen H, Wijnen J, Menko F, et al. Cancer risk in families with hereditary nonpolyposis colorectal cancer diagnosed by mutation analysis. Gastroenterology 1996;110:1020-1027.

56. Syngal S, Weeks J, Schrag D, Garber J, Kuntz K. Benefits of colonoscopic surveillance and prophylactic colectomy in patients with hereditary nonpolyposis colorectal cancer mutations. Ann Intern Med 1998;192:787-796.

57. Church J, Simmang C, Standards Task Force, American Society of Colon and Rectal Surgeons, Collaborative Group of the Americas on Inherited Colorectal Cancer and the Standards Committee of The American Society of Colon and Rectal Surgeons. Parameters for the treatment of patients with dominantly inherited colorectal cancer (familial adenomatous polyposis and hereditary nonpolyposis colorectal cancer). Dis Colon Rectum 2003; 46:1001-1012.

58. Merz J. Disease gene patents: overcoming unethical constraints on clinical laboratory medicine. Clin Chem 1999;45:324-330.

59. Doheny K. Genetic tests for cancer not perfect. HealthDay. March 21, 2006.

60. Myriad Genetics. Clinical update: testing for hereditary breast and ovarian cancer syndrome. Available at: http://www.myriadtests.com/provider/doc/ clinical.update.v4n05.pdf. Accessed November 18, 2009.

61. MRC Holland. SALSA MLPA Kit P002-B1 BRCA1 specification sheet. Amsterdam: MRC Holland, 2008

62. Myriad Genetics Laboratories. BRACAnalysis ${ }^{\circledR}$ technical specifications. Available at: http://www.myriadtests.com/provider/doc/tech_specs_brac. pdf. Accessed December 19, 2007.
63. Page D. FDA approves study for breast cancer risk test by InterGenetics. Journal Record. September 20, 2006.

64. First genetic-based breast cancer risk test available in the U.K. and Ireland Genetic Engineering and Biotechnology News. March 1, 2007. Available at: http://www.genengnews.com/news/bnitem.aspx?name=13573820. Accessed March 9, 2010.

65. Phillips K, Veenstra D, Ramsey S, Van Bebber S, Sakowski J. Genetic testing and pharmacogenomics: issues for determining the impact of healthcare delivery and costs. Am J Manag Care 2004;10:425- 432

66. Myriad Genetics. Myriad reimbursement assistance program. Available at: http://myriadtests.com/mrap.htm. Accessed July 12, 2008.

67. InterGenetics builds DNA analysis and genotyping laboratory; laboratory essential to commercialization of nation's first genetic-based breast cancer risk predictive test applicable to all women. Business Wire. September 7, 2005. Available at: http://findarticles.com/p/articles/mi_m0EIN/is_2005_Sept_7/ ai_n15346276/. Accessed March 9, 2010.

68. Winnick E. Perlegen eyes first-half 2009 launch of breast cancer Dx panel. GenomeWeb News. September 25, 2008.

69. Pinker S. My genome, my self. New York Times Magazine. January 7, 2009. Available at: http://www.nytimes.com/2009/01/11/magazine/11Genome-t. $\mathrm{html}$ ?_r $=2 \& s c p=1 \& s q=$ pinker\&st $=$ cse. Accessed January 21, 2009.

70. O'Connor M. Genetic technologies and breast cancer. Courier-Mail. October 27,2008

71. Shanahan L. Call to act on breast cancer test. The Age. October 28, 2008.

72. Macey J. Company seeks to monopolise breast cancer test. ABC News Radio: The World Today. October 23, 2008. Available at: http://www.abc.net.au/ news/stories/2008/10/23/2399406.htm?site=news. Accessed March 3, 2010.

73. Genetic Technologies to enforce BRCA test rights in Australia, New Zealand. GenomeWeb Daily News. July 21, 2008.

74. Cresswell A. A price on your genes. The Australian. July 30, 2008

75. Macey J. Consumer watchdog investigates gene company. The World Today. October 23, 2008. Available at: http://www.abc.net.au/worldtoday/ content/2008/s2399139.htm. Accessed November 8, 2008.

76. Examination of budget estimates 2008-2009. Additional information received. Health and ageing portfolio. Community Affairs Committee, December 3, 2008

77. Transcript of Senate Standing Committee on Community Affairs Estimates. Community Affairs Committee, October 22, 2008.

78. Genetic Technologies Limited. Intention to appoint a director. Available at: http://www.gtglabs.com.au/announcements/intention-to-appoint-a-director. Accessed March 10, 2010.

79. Caulfield T, Gold ER. Genetic testing, ethical concerns, and the role of patent law. Clin Genet 2000;57:370-375.

80. Centers for Disease Control and Prevention. Genetic testing for breast and ovarian cancer susceptibility: evaluating direct-to-consumer marketingAtlanta, Denver, Raleigh-Durham, and Seattle, 2003. MMWR Morbid Mort Wkly Rep 2004:53:603-606.

81. Mouchawar J, Hensley-Alford S, Laurion S, et al. Impact of direct-toconsumer advertising for hereditary breast cancer testing on genetic services at a managed care organization: a naturally occurring experiment. Genet Med 2006; 7:191-197.

82. Mouchawar J, Laurion S, Ritzwoller D, Ellis J, Kulchak-Rahm A, HensleyAlford S. Assessing controversial direct-to-consumer advertising for hereditary breast cancer testing: reactions from women and their physicians in a managed care organization. Am J Manag Care 2005;11:601-608

83. Schwartz M, Lerman C, Brogan B, et al. Utilization of BRCA1/BRCA2 mutation testing in newly diagnosed breast cancer patients. Cancer Epidemiol Biomarkers Prev 2005;14:1003-1007.

84. Myriad Genetics. Myriad Genetics launches awareness advertising campaign to educate women about hereditary risks of breast and ovarian cancers. Available at: http://investor.myriad.com/releasedetail.cfm?ReleaseID $=325769$. Accessed March 10, 2010.

85. Myriad Genetics. Myriad Genetics reports results for third quarter of fiscal 2008. Available at: http://investor.myriad.com/releasedetail.cfm?ReleaseID= 325474. Accessed November 15, 2009.

86. Shappell HL, Matloff ET. Writing effective insurance justification letters for cancer genetic testing: a streamlined approach. J Genet Couns 2001; 10:331-341.

87. Kieran S, Loescher L, Lim K. The role of financial factors in acceptance of clinical BRCA genetic testing. Genet Test 2007;11:101-110.

88. Economic Research Initiative of the Uninsured. Table 2- CPS adult population (age 19-64) calendar year 2005. Available at: http://www.rwjf-eriu.org/ fastfacts/cps2005_2.html. Accessed January 11, 2010.

89. Kuerer H, Hwang E, Anthony J, et al. Current national health insurance coverage policies for breast and ovarian cancer prophylactic surgery. Ann Surg Oncol 2000; 7:325-332.

90. Kauff N, Scheuer L, Robson M, et al. Insurance reimbursement for riskreducing mastectomy and oophorectomy in women with $B R C A 1$ or $B R C A 2$ mutations. Genet Med 2001;3:422-425.

91. Liu S, Chollet D. Price and income elasticity of the demand for health insurance and health care services: a critical review of the literature. 
Cambridge, MA: Mathematica Policy Research, March 26 2006. Available at: http://www.mathematica-mpr.com/publications/pdfs/priceincome.pdf. Accessed March 9, 2010.

92. NCBI Sequence Viewer. Homo sapiens breast cancer 1. Available at: http:// www.ncbi.nlm.nih.gov/entrez/viewer.fcgi?val=NG_005905.1\&from= $10511 \&$ to $=91665 \& \mathrm{dopt}=\mathrm{gb}$. Accessed June 1, 2007.

93. NCBI Sequence Viewer. Homo sapiens chromosome 13, reference assembly. Available at: http://www.ncbi.nlm.nih.gov/entrez/viewer.fcgi?val=NC_000013. $9 \&$ from $=31787617 \&$ to $=31871809 \&$ dopt $=\mathrm{gb}$. Accessed June 1, 2007.

94. NCBI Sequence Viewer. Homo sapiens chromosome 5, reference assembly. Available at: http://www.ncbi.nlm.nih.gov/entrez/viewer.fcgi?val=NC_ $000005.8 \&$ from $=112101483 \&$ to $=112209835 \&$ dopt $=\mathrm{gb}$. Accessed March 3, 2010

95. NCBI Sequence Viewer. Homo sapiens chromosome 3, reference assembly. Available at: http://www.ncbi.nlm.nih.gov/entrez/viewer.fcgi?val=NC_000002. $10 \&$ from $=47483767 \&$ to $=47563864 \&$ dopt $=\mathrm{gb}$. Accessed March 3, 2010.

96. NCBI Sequence Viewer. Homo sapiens chromosome 2, reference assembly. Available at: http://www.ncbi.nlm.nih.gov/entrez/viewer.fcgi?val= NC_000002.10\&from $=47863790 \&$ to $=47887596 \& d o p t=g b$. Accessed March 3, 2010.

97. Grann V, Jacobson J, Whang W, et al. Prevention with tamoxifen or other hormones versus prophylactic surgery in BRCA1/2-positive women: a decision analysis. Cancer J Sci Am 2000;6:13-20.

98. Hershman D, Sundararajan V, Jacobson J, Heitjan D, Neugut A, Grann V. Outcomes of tamoxifen chemoprevention for breast cancer in very highrisk women: a cost-effectiveness analysis. J Clin Oncol 2002;20:9-16.

99. Eckermann S, Martin A, Stockler M, Simes R. The benefits and costs of tamoxifen for breast cancer prevention. Aust N Z J Public Health 2003; $27: 34-40$.

100. Grann V, Panageas K, Whang W, Antman K, Neugut A. Decision analysis of prophylactic mastectomy and oophorectomy in BRCA1-positive or BRCA2-positive patients. J Clin Oncol 1998;16:979-985.

101. Tengs T, Berry D. The cost effectiveness of testing for the BRCAI and BRCA2 breast-ovarian cancer susceptibility genes. Dis Manag Clin Outcome 2000;1:15-24.

102. National Cancer Institute. Learning about colon cancer. Available at: http://www.genome.gov/10000466. Accessed February 1, 2007.

103. Centers for Disease Control. Colorectal cancer test use among persons aged >50 years-United States, 2001. MMWR Morbid Mort Wkly Rep 2003; 52:193-196.

104. Plaintiffs' Complaint. Association for Molecular Pathology, et al., v. United States Patent and Trademark Office, et al. Civil Action No. 09-4515 (RWS), Southern District of New York (S.D.N.Y.), filed May 12, 2009.

105. Defendant United States Patent and Trademark Office's Memorandum of Law in Support of Motion to Dismiss. Association for Molecular Pathology, et al., v. United States Patent and Trademark Office, et al. Civil Action No. 09-4515 (RWS), S.D.N.Y., filed July 13, 2009.

106. Memorandum of Law in Support of Defendants' Motion to Dismiss. Association for Molecular Pathology, et al., v. United States Patent and Trademark Office, et al. Civil Action No. 09-4515 (RWS), S.D.N.Y., filed July 13, 2009

107. Plaintiffs' Memorandum of Law in Support of Motion to Conduct Jurisdictional Discovery. Association for Molecular Pathology, et al., v. United States Patent and Trademark Office, et al., Civil Action No. 09-4515 (RWS), S.D.N.Y., filed August 26, 2009.

108. Plaintiffs' Memorandum of Law in Support of Motion for Summary Judgment. Association for Molecular Pathology, et al., v. United States Patent and Trademark Office, et al., Civil Action No. 09-4515 (RWS), S.D.N.Y., filed August 26, 2009.

109. Order to Deny Defendants' Motion to Dismiss. Association for Molecular Pathology, et al., v. United States Patent and Trademark Office, et al., Civil Action No. 09-4515 (RWS), S.D.N.Y., filed November 1, 2009.

110. European Patent Office Board of Appeals. Decision of the Technical Board of Appeal 3.3.04 of 13 November 2008, Case No. T 0666/05-3.3.04. European Patent Office Board of Appeals, 2008

111. New European Patent Specification, EP 0705903 B2.

112. John EM, Miron A, Gong G, et al. Prevalence of pathogenic BRCA1 mutation carriers in 5 US racial/ethnic groups. JAMA 2007;298:2869-2876.

113. Pereira LHM, Pineda MA, Rowe WH, et al. The BRCAl Askhenazi founder mutations occur on common haplotypes and are not highly correlated with anonymous single nucleotide polymorphisms likely to be used in genome-wide case-control association studies. BMC Genet 2007;8:68.

114. Zimmeren EV, Requena G. Ex-officio licensing in the medical sector: the French model. In: van Overwalle G, editor. Gene patents and public health. Brussel: Bruylant, 2007:123-147.

115. Overwalle GV. The Belgian compulsory license for public health [translation and summary of Debrulle J, De Cort L, Petit M. La licence obligatoire belge pour raisons de santé publique]. In: van Overwalle G, editor. Gene patents and public health. Brussel: Bruylant, 2007:199-209.

116. Article 21, Council of the European Union Working Document 13706 09. Available at: http://register.consilium.europa.eu/pdf/en/09/st13/ st13706.en09.pdf. Accessed October 20, 2009

117. Genetic Technologies Limited. New position re BRCA testing. Available at: http://www.gtglabs.com.au/announcements/new-position-re-brca-testing. Accessed March 10, 2010.

118. Genetic Technologies Limited (GTG) - ASX listed company information fact sheet. Available at: http://www.asx.com.au/asx/research/companyInfo. do $?$ by $=$ asxCode\&asxCode $=$ GTG. Accessed October 20, 2009.

119. Senate Community Affairs Committee inquiry into gene patents: terms of reference. Available at: http://www.aph.gov.au/senate/committee/clac_ctte/ gene_patents/tor.pdf. Accessed October 20, 2009

120. Inquiry into gene patents - public hearings and transcripts. Available at: http://www.aph.gov.au/senate/committee/clac_ctte/gene patents/hearings/ index.htm. Accessed October 20, 2009

121. Commonwealth of Australia Parliamentary Debates. Senate Community Affairs References Committee: gene patents. Canberra: Commonwealth of Australia Parliamentary Debates, 2009

122. Dayton L. Patently tricky dispute drags on: who owns your genes. The Australian. December 12, 2009. 